\title{
CEsifo \\ WORKING

Government Funding of University-Industry Collaboration: Exploring the Impact of Targeted Funding on

\section{University Patent Activity}

Annita Nugent, Ho Fai Chan, Uwe Dulleck 


\section{Impressum:}

CESifo Working Papers

ISSN 2364-1428 (electronic version)

Publisher and distributor: Munich Society for the Promotion of Economic Research - CESifo

$\mathrm{GmbH}$

The international platform of Ludwigs-Maximilians University's Center for Economic Studies and the ifo Institute

Poschingerstr. 5, 81679 Munich, Germany

Telephone +49 (0)89 2180-2740, Telefax +49 (0)89 2180-17845, email office@cesifo.de

Editor: Clemens Fuest

www.cesifo-group.org/wp

An electronic version of the paper may be downloaded

- from the SSRN website: www.SSRN.com

- from the RePEc website: www.RePEc.org

- from the CESifo website: www.CESifo-group.org/wp 


\title{
Government Funding of University-Industry Collaboration: Exploring the Impact of Targeted Funding on University Patent Activity
}

\begin{abstract}
Government investment in university research results in greater output and impact. To better capture economic benefits stemming from university research, governments have developed funding programs specifically targeting university-industry collaboration. However, little is known about the success of university-industry targeted (U-I targeted) grants. In this study we evaluate the effect of one such scheme, the Australian Research Council (ARC) Linkage Project scheme, by comparing it to its non-targeted sister scheme, the ARC Discovery Project scheme. Having in common selection criteria, grant assessors, awardees, magnitude of funding and duration, the schemes differ in the requirement for an industry partner. We measure capture of economic benefit by patent applications filed and granted. Interrogating the effect of targeted funding at a university level we find award of U-I targeted grants coincides with increased patent activity compared to non-targeted grants. Exploring the dynamics of the relationship, we observe the effect of U-I targeted grants on patent activity is short lived at an inventor level. Further, the propensity for patent activity is influenced by the ratio of U-I targeted to nontargeted grants held at a university level, but not at an inventor level.
\end{abstract}

JEL-Codes: O340, O380.

Keywords: research funding, patent, university-industry collaboration, grants.

Annita Nugent

Centre for Behavioural Economics, Society and Technology, Queensland University of

Technology / Brisbane / Australia

a2.nugent@qut.edu.au
Ho Fai Chan*

Centre for Behavioural Economics, Society and Technology, Queensland University of

Technology / Brisbane / Australia hofai.chan@qut.edu.au

Uwe Dulleck

Centre for Behavioural Economics, Society and Technology

Queensland University of Technology / Brisbane / Australia

uwe.dulleck@qut.edu.au

*corresponding author

We acknowledge the financial support of the Australian Research Council (Award DP180103856). We are grateful to Henri Burgers, Benno Torgler, Grant Woollett, Aidan Byrne and Adam Jaffe for helpful comments and suggestions. 


\section{Introduction}

The importance of innovation as a key factor for sustainable growth has long been acknowledged, with numerous studies linking investment in R\&D to increased productivity (Hall, 2011). Recognizing the role of universities in the innovation cycle, governments tailor funding schemes designed to expedite discovery and innovation in specific technologies, and encourage engagement with the innovation process through collaboration with industry (Etzkowitz \& Leydesdorff, 2000). Although targeted investment in emerging fields of technology, such as nanotechnology (Beaudry \& Allaoui, 2012; Chen et al., 2013; Ponomariov, 2013) and biotechnology (Furman, Murray \& Stern, 2012), has been shown to hasten development in these fields, less is known about the effect of schemes targeting university-industry collaboration on innovation output. Examining the effect of a universityindustry targeted (U-I targeted) scheme, we investigate its correlation with university patent activity, an indicator of innovation output, and compare it to that of a similar non-targeted scheme. We further explore whether the award of a U-I targeted grant precedes patent activity, isolating the award of a single grant at the level of an individual inventor. This study is undertaken in the context of the Australian Research Council (ARC) comparing the effect of the U-I targeted Linkage Project (LP) scheme and the non-targeted Discovery Project (DP) scheme on patent activity.

Research policy has evolved world-wide to stress the importance of connecting academia and industry (Etzkowitz \& Leydesdorff, 2000). Underlining the importance placed on university-industry collaboration and knowledge transfer, many countries run multiple funding schemes, in some cases administered by independent government departments, all purposed with a similar objective. However, evidence of the effectiveness of these schemes is lacking, and as a result there is little scientific basis on which policy makers can decide how to apportion funds between schemes, which should be continued and which should be terminated (Jaffe, 2008, 2015).

Arguably, competition for funding between government agencies is as fierce as it is between researchers. In the United States, for example, research funding is spread across various appropriation bills which are enacted annually, with two of the major government providers of university funding, the National Institutes of Health (NIH) and the National Science Foundation (NSF), receiving funding under separate appropriation bills (BlumeKohout, Kumar \& Sood, 2015). Within a single funding agency various schemes designed to achieve a similar purpose may co-exist, such as the NSF's Industry-University Cooperative 
Research Centers (IUCRC) Program and the Grant Opportunities for Academic Liaison with Industry (GOALI) Proposals, both designed to stimulate collaboration between academic research and industry (Martin-Vega, Seiford \& Senich, 2002).

Similarly, in Australia there are numerous funding agencies administering multiple programs, the ARC being the main funder of university research. The ARC is unique in its administration of two sister schemes, the LP and DP schemes. The ARC LP scheme is an example of a scheme specifically purposed with promoting university-industry collaboration and the capture of economic benefit (Australian Research Council, 2001). In contrast, the non-targeted DP is focused on knowledge advancement as an outcome. Supporting discrete research projects, the two schemes have in common the term and quanta of funding awarded, and the academics who apply for and peer review the submissions. The main difference between schemes is the U-I targeted LP scheme requirement to have an industry partner. Overall, at a university level there is a positive relationship between the number of U-I targeted LP grants awarded to a university, and patent activity. Efficiency of universities in capturing economic value through patent filings with additional U-I targeted grants is illustrated in Figure 1.

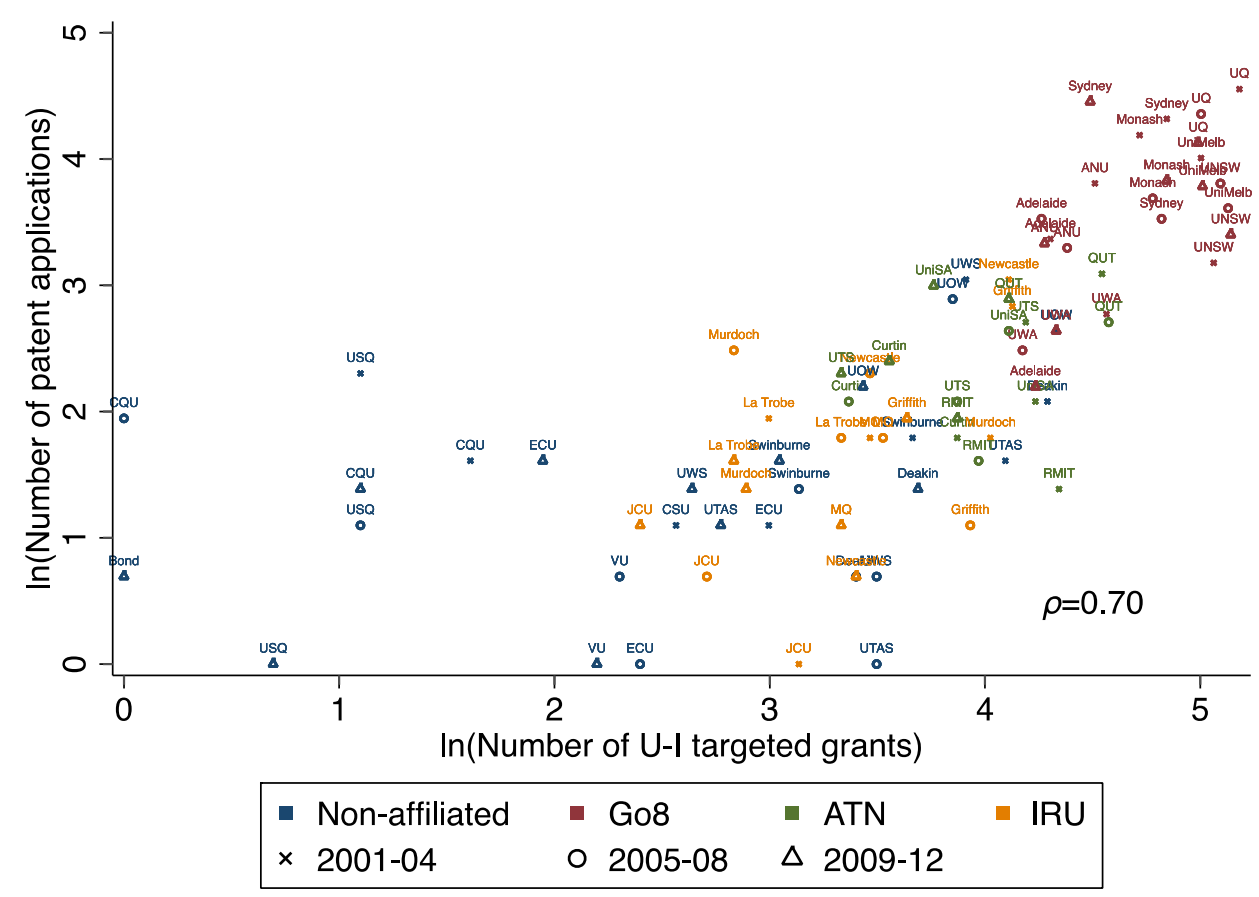

Fig. 1. Relationship between U-I targeted grants awarded and patent applications by university between 2001 and 2012. Universities are grouped into four categories based on affiliation: Group of Eight (Go8), Australian Technology Network of Universities (ATN), Innovative Research Universities (IRU) and non-affiliated (listed in Table A1 in the Appendix). Number of patent 
applications and U-I targeted grants are summed over 2001-04, 2005-08, and 2009-12. Both axis are in log scale. Pearson's correlation $(\rho)$ is 0.7.

Numerous studies link university research output with the award of funding from particular grant schemes. Overall, and unsurprisingly, there is a positive correlation between recipients of grant funding and research output, as gauged by research publications and citations (Arora \& Gambardella, 2005; Averch, 1987; Beaudry \& Allaoui, 2012; Bozeman \& Gaughan, 2007; Zhou et al., 2016). In an attempt to move beyond research output and demonstrate impact, patent data has been used to gauge the capture of economic outcomes (Cheah, 2016). However, these studies do not isolate the effect of government investment in university-industry collaboration on university innovation output above and beyond generic, non-targeted, government support of university research.

Taking advantage of similarities between the ARC LP and DP schemes, this study is novel in differentiating the effect of U-I targeted funding from non-targeted funding on innovation output. Specifically, we will seek to address the question of whether there is a relationship between the award of U-I targeted LP grants and the specified objective of the LP scheme to capture the economic benefits of innovative research (Australian Research Council, 2001), using patents filed by, and granted to, universities as a measure of value capture. Comparing the coincidence of U-I targeted LPs and non-targeted DPs with patent activity, we will determine whether the U-I targeted scheme serves a function that is distinct from that of the non-targeted scheme. Further exploring the dynamics of the relationship between U-I targeted grants and patent activity, we will seek to isolate the effect of being awarded an LP grant on the likelihood of a university inventor filing a patent.

The remainder of this paper is organized as follows: Section 2 provides a review of the literature on research funding and measuring its impact. In Section 3 the context of the study, the ARC, is described and hypotheses developed. Turning to the study proper, Section 4 explains the data and descriptive findings. The model specification is set out in Section 5, followed by a presentation of the results in Section 6 and discussion in Section 7. Overall findings of the study and concluding comments are summarized in Section 8.

\section{Literature}

\subsection{Return on investment of government funded research}

Although investment in $\mathrm{R} \& \mathrm{D}$, both private and government, is used as a barometer of national prosperity by organizations such as the OECD (OECD, 2017), the struggle to isolate 
the independent effects of $R \& D$ expenditure on productivity prevails. Issues in relation to the measurement of both input and output, what is measured and how, exasperate the difficulty of gauging the impact of R\&D intensity on productivity. Extrapolating on the Cobb-Douglas production function Zvi Griliches (Griliches, 1979) introduced a further input, knowledge capital, determined in part by current and past R\&D expenditure, in addition to the conventional inputs of labour and capital.

Subsequent studies have deconstructed the knowledge function and the process by which it influences productivity. Accounting for the fact that it is innovation output, as opposed to innovation input, that drives productivity, Crepon et al (Crepon, Duguet \& Mairessec, 1998) developed a model (CDM) that relates (i) productivity to innovation output, (ii) innovation output to research intensity, and (iii) research to its determinants. Applying the model, they showed that innovation output of French firms, as measured by patent numbers, increased with research efforts, and productivity positively correlated with higher innovation output. With variations of the CDM model being adopted in many subsequent studies (BartzZuccala, Mohnen \& Schweiger, 2018; Hall, 2011), it is efficiency of the middle phase of the model, research intensity to innovation output, that is pursued in the present study.

\subsection{Government funding and innovation output}

Patents are one of the most important indicators for the output of technology-oriented innovation (Grupp, 1998), with the act of filing a patent application a signal of both innovation and intention to capture economic value (James, Leiblein \& Lu, 2013). Although it does not capture all forms of innovation, with some industries favouring keeping trade secrets as a means for protecting of intellectual property, and with many innovations not being patentable inventions, patent behaviour of both firms (Altuzarra, 2019; B. Crepon et al., 1998) and countries (Frietsch, Neuhäusler, Jung \& Van Looy, 2014) has been shown to correlate with economic success. Indeed patenting has been described as one of the most noteworthy indicators of academic commercial activity (Bozeman, 2000).

Overall, most studies investigating the impact of government investment on university research report an uplift in research output subsequent to funding, however the extent is dependent on the characteristics of the specific funding scheme and its environment. Results from an overall study of US federal research funding suggested a \$1million increase in funding would lead to 0.2 more patents (Payne, 2003), with studies linking funding from both the NIH (Azoulay, 2015) and NSF (Averch, 1987) to increased innovation output. However, 
attributes of both the academic and the organization influence the extent of the increase in output (Averch, 1987). As many studies compare funded with non-funded researchers, it is not surprising that the funded researchers have a greater output, as supposedly it is the more talented researchers that are funded (Arora \& Gambardella, 2005).

\subsection{University-industry collaboration and innovation output}

Despite the ubiquitous nature of collaboration in science, its benefits are more often assumed than investigated (Lee, 2005). Substantial theory and empirical evidence links collaboration with productivity and innovation (Bercovitz, 2011). This is based on the premise that innovation is a novel recombination of existing ideas and collaboration increases the library of existing ideas (Burt, 2005; Fleming, 2007). Although most studies examining the effect of collaboration on research output find a positive effect (Bercovitz, 2011; Burt, 2005; Fleming, 2007), others have suggested the impact of collaboration on research output is not so clear (Lee, 2005).

Various explanations have been proposed as to why investment in university-industry collaboration may not reap the expected returns in innovation output. Whilst the benefit to firms of collaborating with universities on subsequent innovation may be varied (Mingji \& Ping, 2014), geographical proximity (Maietta, 2015), social networks and efficient communication channels (Mingji \& Ping, 2014), the nature of the engagement (Hohberger, Almeida \& Parada, 2015), academic policy (Maietta, 2015), and the quality of the collaborating academic institution (Szücs, 2018) do influence innovation output and direction. At a university level it has been suggested the strong positive effect on productivity associated with funding of collaboration may be due to access to additional research resources rather than collaboration per se (Lee, 2005); an alternate motivation for academics engaging with industry being to further their research rather than commercialize their knowledge (D’Este \& Perkmann, 2010). The dynamic nature of the innovation process and the relationship compound the challenge of measuring the association between collaboration incentives and innovation output. For example, uplift in research productivity not observed during the funding cycle may be observed in the long run for collaborations that persist (Defazio, 2009), whilst the role of an industry partner in managing intellectual property may result in decreased patent activity for collaborating academics compared to their noncollaborating colleagues (Bikard, Vakili \& Teodoridis, 2018).

\subsection{The seeding effect of government funding}


In considering the temporal relationship between $R \& D$ investment and innovation output, the knowledge production function model of Griliches, and subsequent variations thereof, place research funding on the input side of the ledger with products of innovations such as patents on the output side, assuming a causal relationship. However, in his seminal work Griliches acknowledged this may be an over simplification, noting that R\&D investments are themselves affected by the level of output, and by past profits and productivity (Griliches, 1979). Although patents are generally considered a product of R\&D activity (Griliches, 1990), instances of contemporaneous relationships (Stoneman, 1983), bidirectional relationships (Altuzarra, 2019; Brouwer, 2001) and reverse unidirectional relationships between past success in innovation and future $\mathrm{R} \& \mathrm{D}$ efficiency (Arora, Ceccagnoli \& Cohen, 2008; Baraldi, Cantabene \& Perani, 2014; Crepon \& Duguet, 1997) have been reported. Suggested explanation for these observations include - as intellectual property protection is secured early during the $R \& D$ stage, significant investment occurs post patenting (Baraldi et al., 2014), and the reinvestment of revenue from patents into R\&D (Baraldi et al., 2014; Hall \& Ziednonis, 2001; Stoneman, 1983).

The majority of studies linking investment in university research with output only look for a positive correlation between funding and output, finding positive though varying relationship at an organization (Adams, 1998; Payne, 2003), project team (Carayol, 2017) and individual (Arora \& Gambardella, 2005; Bornmann, Wallon \& Ledin, 2008; Jacob \& Lefgren, 2011; Zhou et al., 2016) level. As opposed to industry which is more focused on the protection of new innovation and staking out its claim, academics are more concerned with publications (Bikard et al., 2018), and thus less likely to seek patent protection early in the research process. Further the revenue from licence income into a university represents a small portion of total income, thus unlikely to significantly effect R\&D spend.

Innovation is pivotal to increasing productivity, and governments are able to positively manipulate the rate of innovation, accelerating innovation output through investment in $R \& D$, however all investment is not equal. Despite the majority of evidence in the affirmative for the effect of university-industry collaboration on innovation output, challenge has been in disentangling the effect of the collaboration per se with funding (Lee, 2005). Mirroring each other in most regards except for the requirement of an industry partner, the UI targeted LP and non-targeted DP grant schemes of the ARC may provide further insight into the effectiveness of investment in university-industry collaboration. 


\section{Context of the Australian Research Council and hypotheses development}

Established as an independent statutory agency in 2001 (Australian Research Council Act (Cth), 2001), the ARC in its current form replaced the previous council which was under the umbrella of the National Board of Employment, Education and Training (Australian Research Council, 1999; National Board of Employment, 1990). The ARC awards funding, based on peer review, under two major programs; Discovery, focused on knowledge advancement as an outcome, and Linkage which is aimed at strengthening links within the innovation system to capture the economic, social and cultural benefits of research (Australian Research Council, 2001). Each program administers a project funding scheme to support research projects undertaken by individual researchers or research teams. A distinguishing feature of the LP scheme compared to the DP scheme is that each grant must have at least one non-university collaborating organization, and the collaborating organizations must contribute to the project in cash.

Although there is approximately two-fold the number of non-targeted grants awarded compared to U-I targeted grants ${ }^{\mathrm{a}}$, the schemes are analogous in most regards. The 2012 grant rounds awarded funding for up to three years of between $\$ 50,000$ and $\$ 300,000$ per year for LPs and \$30,000 and \$500,000 for DPs (Australian Research Council, 2011, 2012). Drawing on assessors from a common pool, selection criteria for both schemes is based on investigator track record, project innovation, feasibility and research environment, with partner commitment also taken into consideration with respect to LPs (Australian Research Council, 2011, 2012). Between 2001 and 2012, grant size for LPs averaged \$260,000 and for DPs, $\$ 310,000^{\mathrm{b}}$, with more than one-third of ARC grant recipients awarded both U-I targeted and non-targeted grants during the 12-year period.

Compared to the non-targeted scheme, the U-I targeted scheme is designed to foster engagement within the innovation system, and capture the economic value of innovation, through incentivising university engagement with industry stakeholders. Prior to the commencement of a U-I targeted project, parties must contemplate likely forms of intellectual property, and reach agreement as to how newly created intellectual property, and

\footnotetext{
${ }^{a}$ Extracted from Australian Research Council National Competitive Grants Program Dataset (Australian Research Council, 2017)

${ }^{\mathrm{b}}$ Extracted from Australian Research Council National Competitive Grants Program Dataset (Australian Research Council, 2017)
} 
existing background intellectual property owned by the respective parties, will be dealt with (Australian Research Council, 2016). Consideration is given to potential outcomes, and how these will be captured and protected, and how commercialization will be managed. Thus, it would be expected that universities that have greater engagement with industry partners through collaboration on U-I targeted grants will engage more with the patent system.

H1. Award of U-I targeted grants is associated with the filing, and subsequent grant, of more patent applications compared to the award of non-targeted grants.

The underlying rationale for governments to invest in research is to promote innovation, ultimately improving the economy, and it is generally considered government investment does result in increased innovation. However, the difficulty in showing a temporal break in innovation at the point of funding has been acknowledged in previous studies. For example, in a study of New Zealand's Marsden fund the authors contributed the challenge in identifying a time in performance change to noisy data and the sample size being too small (Gush, Jaffe, Larsen \& Laws, 2017). With U-I targeted grants accounting for slightly under $5 \%$ of university income between $2001-2012^{c}$, and most universities receiving a similar quantum of ARC project grants year on end, the effect of additional grants on subsequent patent activity is difficult to detect. The dynamics of the relationship between patent activity and award of grants will be more evident at an inventor level, where a single grant is likely to account for the majority of an individual's research income, increasing the signal-to-noise ratio of holding a grant vis-à-vis not holding a grant.

Almost without exception, funding of university research results in increased innovation output. However, more recently the temporal stability of the relationship between funding of firm R\&D and innovation output has come into question. If this instability is transmitted during interactions between industry and university, a similar reverse causality may be expected in academia with patent activity preceding U-I targeted grants.

\section{H2. The award of U-I targeted grants lags patent activity of inventors.}

If it is the case, as hypothesised, that U-I targeted grants correspond with increased economic value - as measured by patents applied for as well as patent granted - then it would expected that inventors that concentrate on U-I targeted funding to support their research will

\footnotetext{
${ }^{\mathrm{c}}$ Extracted from Australian Research Council National Competitive Grants Program Dataset (Australian Research Council, 2017)
} 
have the highest propensity to apply for, and be awarded, patents. If this hypothesis is rejected, evidence that a mix of targeted and non-targeted funding maximizes the impact of public research funding would be observed.

H3. Innovators with a higher proportion of U-I targeted grants compared to nontargeted grants demonstrate greater patent activity.

\section{Data and descriptive findings}

This study was conducted at a university level in order to determine the association between patent activity and the award of U-I targeted grants, and then at an inventor level with the aim of exploring the dynamics of this relationship. The sample comprises 36 Australian universities, and the complete population of inventors from each of the universities. The study draws upon publicly available data from Australian government agencies for both the focus independent variables, and the two dependent variables, number of patent applications filed and granted patents. The count of LPs and DPs awarded was extracted from the Australian Research Council National Competitive Grants Program Dataset (Australian Research Council, 2015) whilst the IP Australia patent database (IP Australia, 2018) was used to extract counts of patent applications and granted patents. Patent application data is included in the study in addition to patent grant data as it provides a more complete record of invention, and provides greater statistical power as only a fraction of applications proceed to grant (Colatat, 2015).

ARC project grants are counted as of year of submission. For the purpose of this study, the ARC data was limited to project grants in the fields of science, technology, engineering and mathematics (STEM - described in Table A2 in the Appendix), research in these fields being likely to result in patentable subject matter. Patent applications are counted based on the year of filing of the complete application. Granted patents are counted as of year the complete patent application was filed. At the time of the study there were no pending patent applications, with all applications filed between 2001 and 2012 either being granted or lapsed before grant.

Previous studies have reported a number of confounding variables that effect both the likelihood of being awarded funding and research output, including university status, field of research, age of the researcher, and gender. 
Controlling for the effect of university affiliation, dummy variables were included for the network each university was affiliated with; Group of Eight Universities (Go8), Australian Technology Network Universities (ATN) and Industrial Research Universities (IRU), compared to non-affiliated universities. Universities in each of the alliances are unified by their agendas: the Go8 comprising ‘Australia's leading universities', the ATN describing itself as the 'most innovative and enterprising universities in the nation', whilst the IRU members research is 'focussed at the translation of research'. A list of universities and their affiliations is provided in Table A1.

To take into account variations due to research environment, information on university publications and staffing was included from the datasets of a number of government agencies, collected annually (details provided in Table A3 in the Appendix). With perceived and actual institutional support of commercialization activities in research centres being observed to be predictive of invention disclosures, but not patent activity, as measured by patent grants (Hunter, 2011; Meyer \& Tang, 2007), variation in commercialization support was also factored in.

At an inventor level the number of ARC Fellowships was also included, with $40 \%$ of the selection criteria weighted toward researcher track-record ARC Fellowships are informative of endogenous researcher attributes.

Scopus database was used to ascertain the field of research and date of first publication of each researcher. The later was used as a proxy for inventor seniority, with academic age being calculated as time since first publication, as of 2012. Although it has been suggested older researchers are more productive and have greater grant success (Kyvik, 2008), the greatest discoveries are usually made by researchers under forty (Gieryn, 1981). Affiliation data contained in Scopus was used to verify whether the inventor was a university inventor or an industry fellow, and which university the recipient of an ARC award was associated with.

With studies showing that women made up only $10.8 \%$ of inventors in 2013, their patents having a lower technological impact, and associated with a higher number of International Patent Classifications (Sugimoto, Ni, West \& Lariviere, 2015), gender was taken into account in the study. Gender was determined by the first name of the inventor.

\subsection{University sample}

The university sample represents all Australian universities that responded to the national Higher Education Research Data Collection (Universities Australia, 2016) for the 
full period between 2001-2012. The number of STEM project grants awarded to each sample university as administering organization over the twelve-year period tallied 3615 for LPs and 6825 DPs.

A search of the IP Australia database returned 1394 unique patent applications filed between 2001 and 2012 by these universities. In cases where a university had an associated commercialization entity, such as New South Innovation for the University of New South Wales, both names were searched. Patent applications with two or more universities as coapplicants were counted once for each university. At the university-level there were 1510 patent applications and 783 granted patents.

\subsection{Inventor sample}

Sample university patent applications were consolidated, removing duplicate patents. Inventors listed on the sample university patent applications formed the sample inventors. For each inventor the count of patent applications, granted patents, DPs, LPs and ARC Fellowships submitted between 2001 and 2012 was tallied.

The final stage in the data collection was the removal of inventors that were not affiliated with one of the 36 universities at the time of patent filing, for example investigators who were employees of industry co-applicants, and to consolidate inventors which appeared under several names. Unlike the ARC investigator details, inventor details on the IP Australia database are not accurately recorded, and an inventor may appear under several different names, for example John Smith, John C Smith and Jon C Smith. Further in the case of jointly filed patent applications, it is not possible to ascertain from the IP database which organization the inventor was affiliated with. For this reason, inventor details were verified using Scopus database.

Prior to the final stage there were 2807 inventors, upon cleaning the number of unique inventors was reduced to 2468, named as inventors on patent applications 3849 times, granted patents 2094 times and occurring as chief investigators 1523 times on LPs and 1816 times on DPs. During the 12-year period 62.34\% of inventors received neither DP nor LP grants, whilst $16 \%$ were awarded grants under both schemes.

\subsection{Descriptive findings}

Descriptive statistics for each of the variables in the panel data set is presented in Table 1. 


\section{Table 1}

Summary statistics of university and inventor level panel data set - yearly, 2001-2012.

\begin{tabular}{|c|c|c|c|c|c|}
\hline Variable & Mean & Std. Dev & Min. & Max. & $\mathrm{N}$ \\
\hline \multicolumn{6}{|l|}{ University level } \\
\hline Patent applications & 3.50 & 5.41 & 0 & 42 & 432 \\
\hline Granted patents & 1.81 & 3.02 & 0 & 20 & 432 \\
\hline U-I targeted grants & 8.37 & 8.97 & 0 & 41 & 432 \\
\hline Non-targeted grants & 15.80 & 21.25 & 0 & 106 & 432 \\
\hline $\begin{array}{l}\text { Publications per } \\
\text { researcher }\end{array}$ & 4.54 & 7.79 & 1 & 81 & 407 \\
\hline $\begin{array}{l}\text { Comm staff per } \\
\text { researcher }\end{array}$ & 0.06 & 0.19 & 0 & 2 & 407 \\
\hline \multicolumn{6}{|l|}{ Inventor level } \\
\hline Patent applications & 0.13 & 0.40 & 0 & 11 & 29616 \\
\hline Granted patents & 0.07 & 0.28 & 0 & 8 & 29616 \\
\hline U-I targeted grants & 0.05 & 0.24 & 0 & 3 & 29616 \\
\hline Non-targeted grants & 0.06 & 0.25 & 0 & 2 & 29616 \\
\hline Academic age & 18.71 & 11.41 & -5 & 57 & 23832 \\
\hline Female & 0.22 & 0.42 & 0 & 1 & 28488 \\
\hline ARC fellowships & 0.01 & 0.09 & 0 & 2 & 29616 \\
\hline $\begin{array}{l}\text { Publications per } \\
\text { researcher (uni avg) }\end{array}$ & 2.43 & 2.71 & 0 & 53 & 28440 \\
\hline $\begin{array}{l}\text { Comm staff per } \\
\text { researcher (uni avg) }\end{array}$ & 0.03 & 0.11 & 0 & 2 & 28440 \\
\hline
\end{tabular}

Despite U-I targeted grants accounting for only one third of project grants awarded by the ARC, inventors averaged near to as many targeted as non-targeted grants (.84:1), an artefact of LPs having on average more investigators than DPs. The ratio of patent applications to granted patents was marginally over 50\% for both inventors and universities, which is consistent with the conversion rate of patent application to grant reported in previous studies (Michael Carley \& Alan, 2015).

A subset of 930 inventors were chief investigators on U-I targeted and/or non-targeted project grants over the 12-year study period, with 396 holding both. The average 12-year aggregate ratio of U-I targeted grants to combined grants for inventors in this subset was .47. Isolating the effect of a single grant, submitted in the middle year of a 3-year period, recipients of isolated U-I targeted grants were approximately $20 \%$ more likely to file a patent application in the year of submission or following year compared to recipients of an isolated 
non-targeted grant, as shown in Figure 2. Significantly, the patent applications of inventors with isolated U-I targeted grants were almost 30\% more likely to be sealed, which may be an indication of the increased value of the captured technology. Overall, recipients of U-I targeted and non-targeted grants were significantly more likely to file a patent application in the year of submission or subsequent year, compared to years in which they were not awarded project grants.

a)

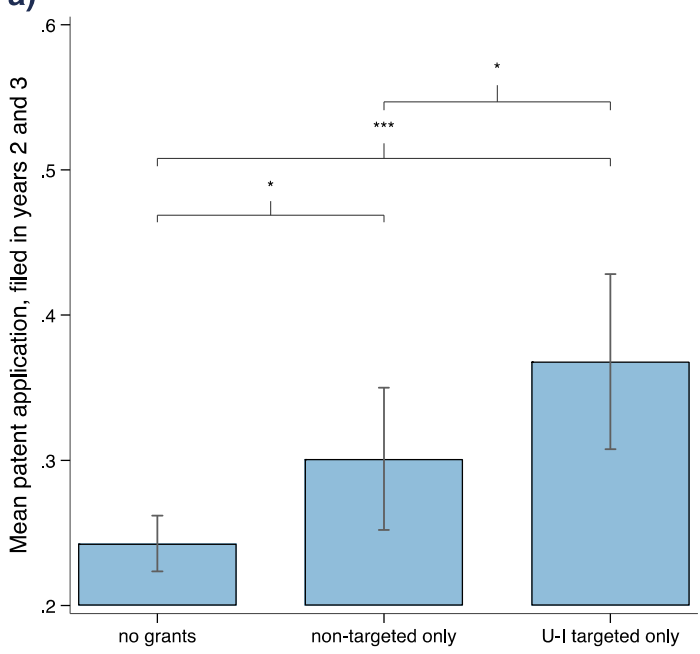

b)

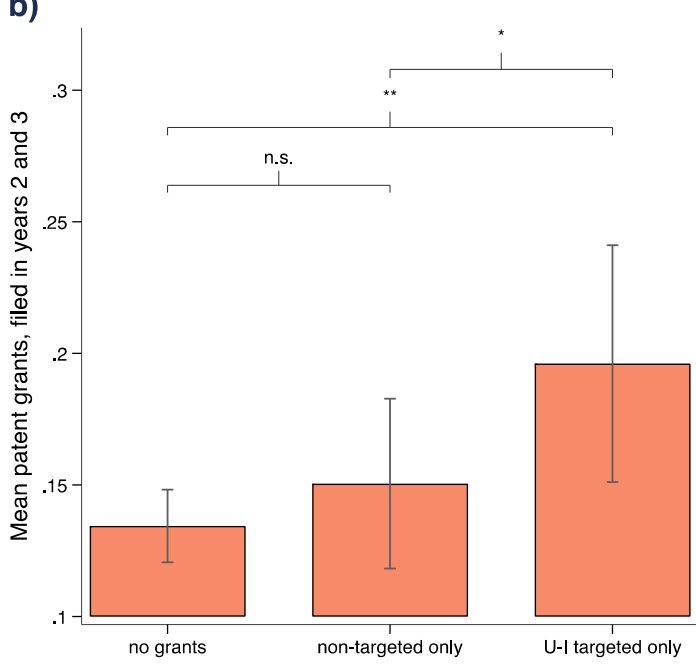

Fig. 2. Isolated ARC grants, submitted in year 2 of a 3-year period, and patent activity in years 2 and 3. Average number of patent applications filed (panel (a)) and granted patents (panel (b)) by academics who are both inventors on patents and chief investigators on ARC grants. Statistical significance for (mean comparison) $t$-test (two-tailed) are shown; n.s. not significant, $* p<0.05$, ** $p<0.01,{ }^{* * *} p<0.001$.

\section{Model specification}

As described above, the goal of the study was to determine whether there is an association between the award of U-I targeted grants and innovation outcomes, at a university level $u$ and examine the dynamics of the association at an individual inventor level $i$. Innovation outcome is operationalized using two independent variables, the number of patent applications filed in a given year $\left[\mathrm{PatApp}_{t}\right]$ and the number of patent applications filed in a given year that were subsequently granted $\left[\mathrm{PatGra}_{t}\right]$.

The focus of the study is on the effect of the U-I targeted LP grant scheme, which is represented by the independent variable number of awarded LPs submitted in a given year $\left[U I-T_{t}\right]$. Being the main source of non-targeted ARC project funding, the number of awarded 
DPs submitted in a given year $\left[N-T_{t}\right]$ was also taken into account. In seeking to explore the dynamics between awarded grants and patent activity, lags for LPs, DPs, and patent activity were allowed for $\left[U I-T_{t-l}\right]$, [N-T $\left.T_{t-l}\right]$, $\left[\right.$ PatApp $\left._{t-1}\right]$ and $\left[\right.$ PatGra $\left._{t-l}\right]$ at an inventor level.

With universities, and many inventors, awarded both U-I targeted and non-targeted grants, to explore interplay between the two the ratio of U-I targeted grants to total grants [UI-TotRat] and total grants [Tot] were used, with an interaction of the ratio allowed for [UITotRat\#].

For controls we use variables associated with the research environment [ResEnv $t_{t}$, such as university affiliation, publications per researcher and commercialization staff per researcher, that contribute to the capability for the university to apply for, and subsequently be granted, patents. We also include year dummies [year] to capture the temporal effects of changes in funding and patent policy.

At an inventor level, to take into account the heterogeneity of the cohort we include inventor attributes [InvAtt $t_{i t}$ in addition to factors influencing the university research environment. Inventor attributes considered include gender, field of research, inventor age as of 2012 measured from year of first publication, and ARC Fellowships.

The models to be estimated can be expressed in a reduced form as:

University level:

$$
\begin{aligned}
& \text { PatApp }_{u t}=f\left(U I-T_{u t}, N-T_{u t}, \text { ResEnv }_{u t}, \text { Year }\right) \\
& \text { PatGra }_{u t}=f\left(U I-T_{u t}, N-T_{u t}, \text { ResEnv } u t, \text { Year }\right)
\end{aligned}
$$

Inventor level:

$$
\begin{aligned}
& \text { PatApp }_{i t}=f\left(U I-T_{i t}, N-T_{i t}, U I-T_{i t-l}, N-T_{i t-l}, \text { PatApp }_{i t-l}, \text { ResEnv }_{i t}, \text { InvAtt }_{i t}, \text { Year }\right) \\
& \text { PatGra }_{i t}=f\left(U I-T_{i t}, N-T_{i t}, U I-T_{i t-l}, N-T_{i t-l}, \text { PatGra }_{i t-l}, \text { ResEnv }_{i t}, \text { InvAtt }_{i t}, \text { Year }\right)
\end{aligned}
$$

Interaction between targeted and non-targeted grants:

$$
\begin{aligned}
& \text { PatApp }=f(\text { Tot, UI-TotRat, UI-TotRat\#, ResEnv, }) \\
& \text { PatGra }=f(\text { Tot, UI-TotRat, UI-TotRat\#, ResEnv, })
\end{aligned}
$$

\section{Results}

The regressions estimate the factors that influence innovation output, as measured by the number of patent applications and granted patents, at a university and inventor level. 
Tables 2 and 3 present at a university level the results of regression models against patent applications and granted patents, respectively. As the dependent variables corresponding to patent activity are both count measures, and the data for the independent variables is overly dispersed, negative binomial regression suitable for panel data was employed in Models 1 to 5. Model 6 employed a mixed effect regression, allowing for the effect of universities nested in clusters as defined by their university affiliation, thus taking into account both fixed effects and random effects ${ }^{\mathrm{d}}$. We also employ robust standard errors clustered at the university level to take into account the non-independence of observations regarding the same university.

Variance inflation factors for the explanatory variables was less than 7 for all variables, reported in Table A4 in the Appendix. Central to the hypothesis of the study is that engagement per se of academia with industry via U-I targeted grant schemes will result in increased patent activity. Consideration was given to including the quantum of funding, as well as total numbers of grants awarded. However, as predicted, there was severe collinearity between number of grants received and funding, hence the latter was excluded from the final regression analysis.

\section{Table 2}

Models for the effect of ARC project grants on university patent applications.

\begin{tabular}{lllllll}
\hline & $(1)$ & $(2)$ & $(3)$ & $(4)$ & $(5)$ & $(6)$ \\
Dep. Var. & Patent apps & Patent apps & Patent apps & Patent apps & Patent apps & Patent apps \\
\hline U-I targ & $0.107^{* * *}$ & & $0.055^{* * *}$ & $0.035^{* *}$ & $0.030^{* *}$ & $0.012 \dagger$ \\
& $(0.012)$ & & $(0.012)$ & $(0.011)$ & $(0.010)$ & $(0.007)$ \\
& 0.447 & & 0.212 & 0.126 & 0.116 & 0.046 \\
Non-targ & & $0.043^{* * *}$ & $0.023^{* * *}$ & $0.018^{* *}$ & $0.017^{* *}$ & 0.001 \\
& & $(0.004)$ & $(0.003)$ & $(0.006)$ & $(0.006)$ & $(0.004)$ \\
Go8 & 0.175 & 0.090 & 0.066 & 0.066 & 0.005 \\
& & & & $0.898^{*}$ & $0.767 \dagger$ & $1.949^{* * *}$ \\
ATN & & & $(0.446)$ & $(0.416)$ & $(0.439)$ \\
& & & & 2.696 & 2.542 & 7.617 \\
IRU & & & $0.824^{* *}$ & $0.623^{*}$ & $0.886^{* *}$ \\
& & & $(0.272)$ & $(0.259)$ & $(0.328)$ \\
Pub/researcher & & & & 0.372 & 1.904 & 1.805 \\
& & & & -0.004 & 0.099 \\
& & & & 0.211 & $(0.262)$ & $(0.369)$ \\
& & & & -0.008 & 0.132 \\
& & & & -0.028 & $-0.041 \dagger$ \\
& & & & $(0.023)$ & $(0.024)$ \\
& & & & -0.107 & -0.163
\end{tabular}

\footnotetext{
${ }^{\mathrm{d}}$ The Hausman test did repute the null hypothesis, returning a significant difference between coefficients when effects of variables were fixed compared to random $\left(\chi^{2}=30.10, p>.001\right)$.
} 
Comm staff/res

$\begin{array}{lll}0.041 & -0.237\end{array}$

\begin{tabular}{lllllll} 
& \multicolumn{9}{c}{} & & & $(0.291)$ & $(0.581)$ \\
& & & & 0.157 & -0.930 \\
\hline Constant & -0.122 & 0.212 & -0.026 & -0.188 & 0.133 & 0.039 \\
Inalpha & $(0.243)$ & $(0.207)$ & $(0.215)$ & $(0.236)$ & $(0.213)$ & $(0.280)$ \\
& $-0.540^{*}$ & $-0.664^{* *}$ & $-0.907^{* * *}$ & $-1.156^{* * *}$ & $-1.244^{* * *}$ & $-2.277^{* * *}$ \\
var(_cons[uni]) & $(0.216)$ & $(0.205)$ & $(0.235)$ & $(0.284)$ & $(0.273)$ & $(0.514)$ \\
& & & & & & $0.376^{*}$ \\
Year dummies & Yes & Yes & Yes & Yes & Yes & $(0.192)$ \\
\hline Obs. & 432 & 432 & 432 & 432 & 407 & Yes \\
N University & 36 & 36 & 36 & 36 & 35 & 35 \\
Log likelihood & -852.1 & -848.4 & -827.2 & -809.4 & -786.4 & -757.3 \\
Wald $\chi 2$ & 125.4 & 143.7 & 237.1 & 307.1 & 329.5 & 269.6 \\
Prob. $>\chi 2$ & 0.000 & 0.000 & 0.000 & 0.000 & 0.000 & 0.000 \\
\hline
\end{tabular}

Notes: $\dagger p<0.1, * p<0.05, * * p<0.01, * * * p<0.001$. Standard errors clustered at university level in parentheses. Marginal effects in italics. Models 1 to 5 employ negative binomial (NBREG) regression. Model 6 employs mixed effects negative binomial (MENBREG) model, allowing for the effect of university affiliation.

\section{Table 3}

Models for the effect of ARC project grants on university patent grants.

\begin{tabular}{|c|c|c|c|c|c|c|}
\hline & (1) & (2) & (3) & (4) & (5) & (6) \\
\hline Dep. Var. & $\begin{array}{l}\text { Patent } \\
\text { grants }\end{array}$ & $\begin{array}{l}\text { Patent } \\
\text { grants }\end{array}$ & $\begin{array}{l}\text { Patent } \\
\text { grants }\end{array}$ & $\begin{array}{l}\text { Patent } \\
\text { grants }\end{array}$ & $\begin{array}{l}\text { Patent } \\
\text { grants }\end{array}$ & $\begin{array}{l}\text { Patent } \\
\text { grants }\end{array}$ \\
\hline \multirow[t]{3}{*}{ U-I targ } & $0.104^{* * *}$ & & $0.060 * * *$ & $0.041^{* * *}$ & $0.038 * *$ & $0.024^{*}$ \\
\hline & $(0.011)$ & & $(0.011)$ & $(0.012)$ & $(0.012)$ & $(0.010)$ \\
\hline & 0.214 & & 0.116 & 0.076 & 0.075 & 0.047 \\
\hline \multirow[t]{3}{*}{ Non-targ } & & $0.042 * * *$ & $0.021 * * *$ & $0.014^{*}$ & $0.013^{*}$ & 0.002 \\
\hline & & (0.005) & (0.003) & (0.005) & (0.005) & (0.005) \\
\hline & & 0.087 & 0.040 & 0.025 & 0.026 & 0.004 \\
\hline \multirow[t]{3}{*}{ Go8 } & & & & $1.081 * *$ & $0.959 *$ & $1.761 * * *$ \\
\hline & & & & $(0.408)$ & $(0.386)$ & (0.483) \\
\hline & & & & 1.609 & 1.562 & 3.109 \\
\hline \multirow[t]{3}{*}{ ATN } & & & & $0.880 * *$ & $0.714 * *$ & $0.877 * *$ \\
\hline & & & & $(0.282)$ & $(0.265)$ & (0.300) \\
\hline & & & & 1.165 & 1.011 & 0.906 \\
\hline \multirow{3}{*}{ IRU } & & & & 0.380 & 0.204 & 0.281 \\
\hline & & & & $(0.276)$ & $(0.263)$ & (0.315) \\
\hline & & & & 0.382 & 0.220 & 0.209 \\
\hline \multirow[t]{3}{*}{ Pub/researcher } & & & & & -0.016 & -0.028 \\
\hline & & & & & $(0.022)$ & $(0.026)$ \\
\hline & & & & & -0.031 & -0.054 \\
\hline \multirow{3}{*}{$\begin{array}{l}\text { Comm } \\
\text { staff/researcher }\end{array}$} & & & & & 0.013 & -0.188 \\
\hline & & & & & $(0.376)$ & (0.523) \\
\hline & & & & & 0.026 & -0.362 \\
\hline \multirow[t]{2}{*}{ Constant } & $-0.677 * *$ & -0.316 & $-0.588 * *$ & $-0.854 * * *$ & $-0.612 * *$ & $-0.647^{*}$ \\
\hline & $(0.231)$ & $(0.210)$ & $(0.204)$ & $(0.242)$ & $(0.237)$ & $(0.281)$ \\
\hline \multirow[t]{2}{*}{ lnalpha } & $-0.682 *$ & $-0.649 * *$ & $-0.980 * * *$ & $-1.218 * * *$ & $-1.249 * * *$ & $-1.825 * * *$ \\
\hline & (0.273) & $(0.221)$ & $(0.277)$ & $(0.321)$ & $(0.322)$ & $(0.427)$ \\
\hline
\end{tabular}


$\operatorname{var}\left(\_c o n s[u n i]\right)$

\begin{tabular}{lllllll} 
Year dummies & Yes & Yes & Yes & Yes & Yes & Yes \\
\hline Obs. & 432 & 432 & 432 & 432 & 407 & 407 \\
N University & 36 & 36 & 36 & 36 & 35 & 35 \\
Log likelihood & -638.5 & -643.7 & -622.4 & -608.7 & -597.7 & -588.6 \\
Wald $\chi 2$ & 167.7 & 186.4 & 286.5 & 463.8 & 565.7 & 379.7 \\
Prob. $>\chi 2$ & 0.000 & 0.000 & 0.000 & 0.000 & 0.000 & 0.000 \\
\hline Notes: $\dagger p<0.1, *$ & $p<0.05, * *$ & $p<0.01, * * *$ & $p<0.001$. Standard errors clustered at university level in
\end{tabular}

Notes. $\uparrow p<0.1, * p<0.05, \quad p<0.01, \quad, \quad p<0.001$. Standard errors clustered at university level in parentheses. Marginal effects in italics. Models 1 to 5 employ negative binomial (NBREG) regression. Model 6 employs mixed effects negative binomial (MENBREG) model, allowing for the effect of university affiliation.

As hypothesised, at a university level the number of patent applications (Table 2) and granted patents (Table 3) correlate significantly with both the number of U-I targeted (Model 1) and non-targeted (Model 2) grants awarded. The correlation is retained when targeted and non-targeted grants are factored together (Model 3), and with the introduction of university affiliation (Model 4) and research environment (Model 5). Although the magnitude of results varies across models, the co-efficient for U-I targeted grants is consistently in the order of two-fold larger than the co-efficient for non-targeted grants, the latter losing significance when mixed effects of variables is allowed for (Model 6). With respect to research environment, university affiliation did positively correlate with patent activity at a university level for the Go8 and ATN alliances compared to non-aligned universities, for both patent application and grant (Models 4 to 7).

Models 1 to 4 of Tables 2 and 3 (university level) are replicated at an inventor level in Tables 4 and 5. Estimates of the control variables are provided in Table A5 and A6 in the Appendix, respectively. Similar trends were returned at an inventor level for both patent applications (Table 4) and granted patents (Table 5), with U-I targeted grants consistently having a stronger correlation with patent activity compared to non-targeted grants. Ceteris paribus, an additional U-I targeted grant awarded to a university is associated with 0.126 additional patent application filed and 0.076 patent application proceeding to grant (Model 4, Tables 2 and 3). At an inventor level, obtaining an additional U-I targeted grant increases the number of patent application filed by 0.041 and granted patent by 0.033 (Model 4, Tables 4 and 5). In contrast, an additional non-targeted grant is only associated with 0.026 and 0.007 increase in patent applications and granted patents at an inventor level.

There was a weak, but highly significant correlation between patent activity and academic age, however no correlation was observed with gender. Whereas ARC Fellowships correlated with patent applications, the correlation with granted patents was insignificant. 
Factors contributing to research environment did not correlate with patent activity, however unexpectedly there was a relatively strong negative correlation between commercialisation staff per research staff and both patent applications and granted patents.

In order to address Hypothesis 2 and explore the dynamic relationship between patent activity and the award of ARC project grants, the introduction of lagged variables of both the dependent variable and independent variables into the model was required, making standard regression estimators inconsistent. As an alternate, a generalized method of moments (GMM) estimator, suitable for datasets with many panels and few periods, was used to investigate the dynamic relationship (Models 5 and 6). Generally considered to generate more efficient estimates of dynamic panel data, GMM accounts for the violation of strict exogeneity, which occurs when internal lag variables are used. The criteria set by Bond ( 2001) was used to select the more appropriate GMM estimator between the differential estimator (Arellano \& Bond, 1991) and system estimator (Arellano \& Bover, 1995; Blundell, 1998). A one-step differential model of GMM employing Roodman's collapse option (Roodman, 2009) to restrict over-inflation of variables was chosen, returning a co-efficient for the lagged dependent variable closer to that generated by a pooled OLS model than a fixed effect model (comparative results for coefficients tabled in Table A7). The AR(1) and AR(2) tests confirmed goodness of fit of the GMM-diff model. As the Hansen statistic becomes inflated with an increasing number of instruments, reducing confidence in the p-value (Roodman, 2009), we reject the null hypothesis of exogeneity of lagged instruments based on the slightly higher than significant $p$-value.

Regressing variables that are non-stationary returns spurious results, hence the stationary nature of the data was confirmed using the Harris-Tzavalis root test. Assuming the number of panels tends to infinity while the number of time periods is fixed, this test is suitable to deal with the 2000 plus panels in the inventor data. A maximum lag-length of 2 years was chosen, this in consistent with previous studies that deal with similar variables (Altuzarra, 2019; Baraldi et al., 2014) and, as the time period is relatively short at 12 years, preserves degrees of freedom.

\section{Table 4}

Models for the effect of ARC project grants on inventor patent applications.

\begin{tabular}{lcccccc}
\hline & $(1)$ & $(2)$ & $(3)$ & $(4)$ & $(5)$ & $(6)$ \\
Dep.Var. & Patent apps & Patent apps & Patent apps & Patent apps & Patent apps & U-I targ
\end{tabular}




\begin{tabular}{|c|c|c|c|c|c|c|}
\hline U-I targ & $\begin{array}{c}0.430 * * * \\
(0.059) \\
0.055\end{array}$ & & $\begin{array}{c}0.380 * * * \\
(0.061) \\
0.048\end{array}$ & $\begin{array}{c}0.303^{* * *} \\
(0.063) \\
0.041\end{array}$ & $\begin{array}{c}0.114 \\
(0.208)\end{array}$ & \\
\hline Non targ & & $\begin{array}{c}0.363 * * * \\
(0.059) \\
0.046\end{array}$ & $\begin{array}{c}0.299 * * * \\
(0.061) \\
0.038\end{array}$ & $\begin{array}{c}0.193 * * \\
(0.063) \\
0.026 \\
-0.076\end{array}$ & $\begin{array}{l}0.255 \dagger \\
(0.136)\end{array}$ & $\begin{array}{c}0.038 \\
(0.135)\end{array}$ \\
\hline L.Patent apps & & & & & $\begin{array}{l}0.055^{*} \\
(0.023)\end{array}$ & $\begin{array}{l}-0.013 \\
(0.014)\end{array}$ \\
\hline L2.Patent apps & & & & & $\begin{array}{l}0.022^{*} \\
(0.010)\end{array}$ & $\begin{array}{c}0.006 \\
(0.008)\end{array}$ \\
\hline Patent apps & & & & & & $\begin{array}{c}0.174 \\
(0.224)\end{array}$ \\
\hline L.U-I targ & & & & & $\begin{array}{c}0.033 \\
(0.025)\end{array}$ & $\begin{array}{c}-0.070 * * \\
(0.021)\end{array}$ \\
\hline L2.U-I targ & & & & & $\begin{array}{l}-0.024 \\
(0.021)\end{array}$ & $\begin{array}{l}-0.041^{*} \\
(0.020)\end{array}$ \\
\hline L.non targ & & & & & $\begin{array}{l}0.069 * \\
(0.029)\end{array}$ & $\begin{array}{c}0.015 \\
(0.030)\end{array}$ \\
\hline L2.non targ & & & & & $\begin{array}{l}0.048 \dagger \\
(0.026)\end{array}$ & $\begin{array}{c}0.001 \\
(0.026) \\
\end{array}$ \\
\hline Constant & $\begin{array}{c}-2.133^{* * *} \\
(0.060)\end{array}$ & $\begin{array}{c}-2.133 * * * \\
(0060)\end{array}$ & $\begin{array}{c}-2.149 * * * \\
(0.060)\end{array}$ & $\begin{array}{c}-2.482 * * * \\
(0126)\end{array}$ & & \\
\hline lnalpha & $\begin{array}{c}0.128 \\
(0.127)\end{array}$ & $\begin{array}{c}0.130 \\
(0.127)\end{array}$ & $\begin{array}{c}0.115 \\
(0.128)\end{array}$ & $\begin{array}{c}0.088 \\
(0.133)\end{array}$ & & \\
\hline $\begin{array}{l}\text { Controls } \\
\text { Year dummies }\end{array}$ & $\begin{array}{l}\text { Not incl. } \\
\text { Incl. }\end{array}$ & $\begin{array}{l}\text { Not incl. } \\
\text { Incl. }\end{array}$ & $\begin{array}{l}\text { Not incl. } \\
\text { Incl. }\end{array}$ & $\begin{array}{l}\text { Incl. } \\
\text { Incl. }\end{array}$ & $\begin{array}{l}\text { Incl. } \\
\text { Incl. }\end{array}$ & $\begin{array}{l}\text { Incl. } \\
\text { Incl. }\end{array}$ \\
\hline Obs. & 29616 & 29616 & 29616 & 22788 & 17091 & 17091 \\
\hline $\mathrm{N}$ Inventor & 2468 & 2468 & 2468 & 1899 & & \\
\hline Log likelihood & -11647.6 & -11655.0 & -11635.7 & -9205.2 & & \\
\hline Wald $\chi 2$ & 266.4 & 252.0 & 294.4 & . & & \\
\hline Prob. $>\chi^{2}$ & 0.000 & 0.000 & 0.000 & . & 0.000 & 0.590 \\
\hline
\end{tabular}

Table 5

Models for the effect of ARC project grants on inventor patent grants.

\begin{tabular}{lcccccc}
\hline Dep. Var. & $\begin{array}{c}(1) \\
\text { Patent } \\
\text { grants }\end{array}$ & $\begin{array}{c}(2) \\
\text { Patent } \\
\text { grants }\end{array}$ & $\begin{array}{c}(3) \\
\text { Patent } \\
\text { grants }\end{array}$ & $\begin{array}{c}(4) \\
\text { Patent } \\
\text { grants }\end{array}$ & $\begin{array}{c}(5) \\
\text { Patent } \\
\text { grants }\end{array}$ & $\begin{array}{c}\text { U-I targ } \\
\text { U-I targ }\end{array}$ \\
& $0.573^{* * *}$ & & $0.544^{* * *}$ & $0.467^{* * *}$ & -0.014 & \\
& $(0.077)$ & & $(0.077)$ & $(0.082)$ & $(0.171)$ & \\
Non targ & 0.038 & & 0.036 & 0.033 & & \\
& & $0.282^{* * *}$ & $0.184^{*}$ & 0.094 & -0.009 & 0.095 \\
& & $(0.083)$ & $(0.085)$ & $(0.090)$ & $(0.102)$ & $(0.130)$ \\
L.Patent grants & & 0.019 & 0.012 & 0.007 & & \\
L2.Patent & & & & & $0.061^{*}$ & -0.012 \\
& & & & & $0.031)$ & $0.025)$ \\
\end{tabular}


grants

(0.011) (0.012)

Patent grants

L.U-I targ

$(0.388)$

L2.U-I targ

$-0.003$

$-0.065^{* *}$

(0.019)

(0.020)

L2.U-I targ

$-0.019$

$-0.047^{*}$

L.non targ

(0.017)

$(0.020)$

0.025

0.030

(0.021)

$(0.027)$

L2.non targ

0.009

0.012

(0.019)

(0.025)

\begin{tabular}{|c|c|c|c|c|c|c|}
\hline Constant & $\begin{array}{c}-2.685 * * * \\
(0.079)\end{array}$ & $\begin{array}{c}-2.668 * * * \\
(0.079)\end{array}$ & $\begin{array}{c}-2.693 * * * \\
(0.079)\end{array}$ & $\begin{array}{c}-2.900 * * * \\
(0.178)\end{array}$ & & \\
\hline lnalpha & $\begin{array}{c}0.757 * * * \\
(0.145)\end{array}$ & $\begin{array}{c}0.787 * * * \\
(0.144)\end{array}$ & $\begin{array}{c}0.754 * * * \\
(0.146)\end{array}$ & $\begin{array}{c}0.784 * * * \\
(0.142)\end{array}$ & & \\
\hline $\begin{array}{l}\text { Controls } \\
\text { Year dummies }\end{array}$ & $\begin{array}{l}\text { Not incl. } \\
\text { Incl. }\end{array}$ & $\begin{array}{l}\text { Not incl. } \\
\text { Incl. }\end{array}$ & $\begin{array}{l}\text { Not incl. } \\
\text { Incl. }\end{array}$ & $\begin{array}{l}\text { Incl. } \\
\text { Incl. }\end{array}$ & $\begin{array}{l}\text { Incl. } \\
\text { Incl. }\end{array}$ & $\begin{array}{l}\text { Incl. } \\
\text { Incl. }\end{array}$ \\
\hline Obs. & 29616 & 29616 & 29616 & 22788 & 17091 & 17091 \\
\hline $\mathrm{N}$ Inventor & 2468 & 2468 & 2468 & 1899 & & \\
\hline Log likelihood & -7318.6 & -7339.4 & -7316.3 & -5783.5 & & \\
\hline Wald $\chi 2$ & 141.0 & 92.5 & 144.6 & . & & \\
\hline Prob. $>\chi 2$ & 0.000 & 0.000 & 0.000 & . & 0.000 & 0.001 \\
\hline
\end{tabular}

The filing of patent applications (Model 5, Table 5) and granted patents (Model 5, Table 6) in previous years did positively correlate with patent activity in the current year. Allowing for the effect of lagged patent and grant activity washed out the correlation between patent activity and U-I targeted grants in the current year, with no correlation observed between patent activity and U-I targeted grants in previous years. Interestingly, there was a weak correlation between non-targeted grants in the same and previous year and patent applications, though this did not transfer to granted patents.

Allowing for the reverse relationship, patent activity was regressed against U-I targeted grants in Model 6, returning no evidence to suggest patent activity in previous years influences U-I targeted grants. Award of U-I targeted grants in previous years correlated negatively with U-I targeted grants in future years. This may be explained by the fact that the grants run over three years, and hence inventors do not apply in consecutive rounds. Regressing the 4-year lag of U-I targeted grants against U-I targeted grants we do not see any evidence of correlation, however the reduction in degrees of freedom compromises the reliability of this result. 
In order to address the third hypothesis, whether there is an interaction between the U-I targeted and non-targeted grants, the ratio of U-I targeted grants to total combined grants was introduced. The effect of the U-I targeted grants as a portion of total grants on patent activity is shown at a university level and an inventor level in Tables 6 and 7, respectively. As it is rare for an inventor to be awarded multiple grants in a given year, the regressions were performed on 12-year aggregate data. Similarly, at a university level 12-year aggregate data was employed.

\section{Table 6}

Models for the effect of ratio U-I targeted grants to non-targeted grants on university patent activity (12-year aggregate).

\begin{tabular}{lcccc}
\hline Dep. Var. & $(1)$ & $(2)$ & $(3)$ & $(4)$ \\
\hline Ratio (U-I targ:Total) & Patent apps & Patent apps & Patent grants & $\begin{array}{c}\text { Patent grants } \\
\text { Ratio }\end{array}$ \\
& $(1.943$ & $6.152 \dagger$ & -0.625 & $7.128^{*}$ \\
Total (U-I+non targ) & $0.002^{* * *}$ & $(3.737)$ & $(0.967)$ & $(2.864)$ \\
& $(0.000)$ & $-6.702 \dagger$ & & $-7.466^{*}$ \\
& & $(3.916)$ & & $(3.068)$ \\
Constant & $3.140^{* * *}$ & $1.003^{* * *}$ & $0.002^{* * *}$ & $0.003^{* * *}$ \\
& $(0.534)$ & $(0.961)$ & $(0.000)$ & $(0.001)$ \\
lnalpha & $-1.251^{*}$ & $-1.380^{* *}$ & $-1.775^{* *}$ & $-2.065^{* * *}$ \\
& $(0.488)$ & $(0.458)$ & $(0.568)$ & $(0.564)$ \\
\hline Obs. & 35 & 35 & 35 & 35 \\
N University & & & & \\
Log likelihood & -139.6 & -137.8 & -114.7 & -111.8 \\
Wald $\chi 2$ & 181.0 & 191.5 & 193.2 & 249.2 \\
Prob. $>\chi 2$ & 0.000 & 0.000 & 0.000 & 0.000 \\
\hline
\end{tabular}

Notes: $\dagger p<0.1, * p<0.05, * * p<0.01, * * * p<0.001$. NBREG regression. Standard errors are shown in in parentheses. Estimates for control variables are reported in Table A8 in Appendix.

\section{Table 7}

Models for the effect of ratio U-I targeted grants to non-targeted grants on inventor patent activity (12-year aggregate).

(1)

\begin{tabular}{lcccc} 
Dep. Var. & Patent apps & Patent apps & Patent grants & Patent grants \\
\hline Ratio (U-I targ:Total) & $0.265^{* * *}$ & $0.746^{*}$ & $0.391^{* * *}$ & $0.832 \dagger$ \\
& $(0.080)$ & $(0.304)$ & $(0.115)$ & $(0.454)$ \\
Ratio $^{2}$ & & -0.484 & & -0.439 \\
& & $(0.303)$ & & $(0.437)$ \\
Total (U-I+non targ) & $0.025^{* *}$ & 0.016 & $0.038^{* *}$ & $0.030^{*}$ \\
& $(0.009)$ & $(0.011)$ & $(0.012)$ & $(0.014)$ \\
\hline Constant & -0.280 & -0.293 & $-0.809 *$ & $-0.824 * *$
\end{tabular}


Obs.

(0.416)

(0.303)

(0.310)

$\mathrm{N}$ Inventors

Log likelihood

826

826

826

Wald $\chi 2$

Prob. $>\chi^{2}$

$-1334.3$

$-1333.0$

$-1092.9$

$-1092.4$

Notes: $\dagger p<0.1, * p<0.05, * * p<0.01, * * * p<0.001$. NBREG regression. Standard errors are shown in parentheses. Estimates for control variables are reported in Table A9 in Appendix.

At an inventor level there is a strong linear relationship between patent activity and the ratio of U-I targeted grants to total grants. However, at a university level a moderately significant non-linear effect is observed between the patent activity and U-I targeted grants as a fraction of total grants. Figure 3 shows the optimal marginal effect on patent activity is when a university holds a fair mix of U-I targeted and non-targeted grants, slightly biased to non-targeted grants. In contrast, an inventor's propensity to engage with patents grows as the ratio of U-I targeted to non-targeted grants increases.
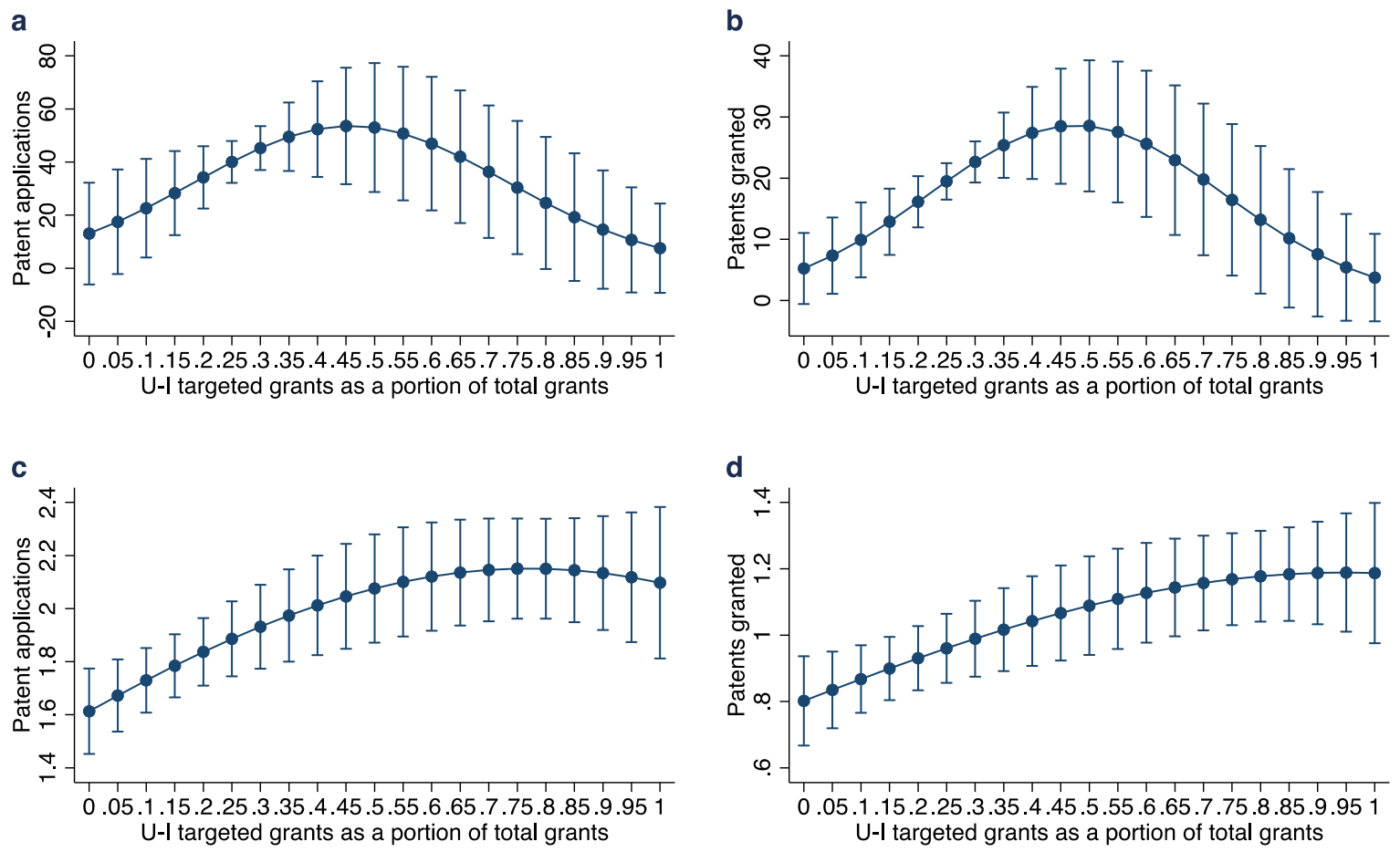

Fig. 3. Marginal effects of ratio of U-I targeted grants to total grants on patent activity at a university level (panel a and panel b - Table 6 Models 2 and 4, respectively) and inventor level (panel c and panel d - Table 7 Models 2 and 4, respectively). 


\section{Discussion}

Our results showed a positive correlation at both a university and an inventor level between patent activity and the award of U-I targeting LP grants, with the correlation stronger at an inventor level. This is to be expected with the U-I targeted grant scheme accounting for around 5\% of university research income, whereas at an inventor level, award of a U-I targeted grant would generally represent a significant portion of research income for an individual.

Encouragingly for the U-I targeting LP scheme, overall patent activity was more strongly correlated with the award of U-I targeted grants compared to non-targeted DPs. These findings suggest that the ARC U-I targeting scheme is not only achieving its intended objective of capturing benefit from research, but that the U-I targeting scheme is serving a distinct function to the non-targeted DP grant scheme. With the non-targeted DP scheme purposed with supporting knowledge advancement, it is reassuring that the outcomes of the two schemes can be distinguished both at an organizational and individual level.

The benefit of U-I targeted grants may be in adding value to a discovery post patent application stage, increasing the likelihood of a patent being granted. At a university level the correlation between U-I targeted grants and patent activity was similar in size for both patent applications and granted patents. However, at an individual level, U-I targeted grants had a stronger correlation with granted patents compared to patent applications. This is in line with initial observations that inventors with an isolated U-I grant were $20 \%$ more likely to file a patent application in the subsequent years, and the patent application was $30 \%$ more likely to proceed to grant, compared to inventors holding an isolated non-targeted grant.

Interesting is the synergistic effect of the U-I targeted and non-targeted grants at a university level, which was not observed at an inventor level. A ratio of slightly less than one U-I targeted grants to one non-targeted grant yielded maximum prediction of patent activity. This suggests that at an organisational level it is important to have a mix of fundamental and applied research to maximize the capture of economic benefit, with individuals within the organisation focusing on one stream of research or the other. However, at an inventor level this observation may not truly account for the multifaceted relationship between basic discovery and the stock of knowledge that inventions ultimately draw upon. A limitation in aggregating grant success over time is that it is not possible to observe the influence of one form of grant preceding the other. Further, although we attempt to take into account the 
attributes of individual inventors, there may be an unidentified bias of inventors to engage in one scheme over the other, such as academic prestige.

A variable worthy of further investigation is the number of commercialization staff per researcher. Although there was no correlation between patent activity and commercialization staff at a university level, surprisingly there was a significant negative correlation between commercialization staff and both patent applications and granted patents at an inventor level. It is the function of the university commercialization office to manage the patenting process (Van Looy et al., 2011). Many organizations adopt a strategy of filing a patent application at an early stage in the innovative process, while still evaluating the economic potential (Lanjouw, Pakes \& Putnam, 1998). Applications are then triaged during the prosecution process based on the potential value of the invention. A more efficient technology transfer office may have fewer granted patents in its portfolio, but each more likely of capturing potential value. During the study period there was a trend for smaller universities to outsource commercialization activities to universities with large technology transfer offices. For this reason, the number of commercialization staff may be under-inflated in some instances, and over-inflated in others.

Observation of a similar effect at both a university and inventor level of granularity indicates that the correlation between U-I targeted grants and patent activity is not a result of the domineering effect of the university to which an inventor belongs. The correlation between university affiliation and patent activity for the Go8 and ATN university alliances at a university level may be explained by the infrastructure these universities have in place to support patenting activities, the collective effect of which is significant at an organizational level. At an inventor level seniority correlated positively with both patent applications and granted patents. This could be due to researchers becoming more commercially savvy with experience, despite their most creative years being behind them (Gieryn, 1981).

Turning to Hypothesis 2, the unexpected correlation between non-targeted grants in previous years and patent applications was made more surprising by the lack of correlation between previously awarded U-I targeted grants and patent activity. The lack of correlation between lagged U-I grants and patent activity, and vice versa may be explained by the various scenarios that lead to the submission of a U-I targeted grant (i) it could signify the start of a new collaboration with an industry partner, and a new project, in which case patent filings will lag behind U-I targeted submissions, (ii) there may be an existing collaboration which has already generated intellectual property, and the parties are looking to further 
develop this, or (iii) the university may have background intellectual property which the partner organization wishes to collaborate on to further develop. In the third scenario it is not uncommon for a university to file a patent application immediately prior to formally entering a collaboration so as to clearly mark out university background IP. In two of the three scenarios, where background IP exists, the relationship between submitting a U-I targeted grant and filing a patent application will not be causal.

The lack of a correlation between patent activity and U-I targeted grants in previous years may be due to the difficulty in pin-pointing the project commencement. For the purpose of the regressions, time zero is the year of filing for both patents and ARC grants, however this does not represent a definitive start date. Although non-targeted DP grants commence officially after announcement of award, commencement of U-I targeted LP grants may be delayed for up to 2 years. Funding rules for LP grants stipulate that a project cannot commence until a collaborative research agreement is in place between all parties, effectively deferring commencement. Similarly, although the term of a patent is determined from the date the complete patent application was filed, and legal rights can only be asserted back to that date, it is the norm for applicants to initiate patent protection by filing a provisional patent application up to 12-months prior to lodging the complete application. Thus, it is difficult to accurately pin down the sequence of events.

\section{Conclusion}

Innovation output, as measured by patent activity, correlates with the award of U-I targeted grants at both a university and inventor level, the correlation being stronger at an inventor level. Patent activity is more closely associated with the award of U-I targeted grants compared to non-targeted grants. However, at a university level an interaction effect is observed suggesting an optimal ratio of U-I targeted to non-targeted grants, in favour of the later, is preferable to either U-I targeted or non-targeted grants exclusively. At a university level U-I targeted grants had an equivalent effect on patent applications and granted patents, whereas at an inventor level the association with patent grants was stronger.

In relation to the dynamics of the relationship between U-I targeted grants and patent activity, we observe no evidence to suggest that one exists. This lack of evidence is unsurprising given the challenge in accurately time stamping activities. Although the year of grant submissions is accurately recorded, the true commencement date of a U-I targeted project may be delayed by several years. 
Overall, our findings lead to the conclusion that the U-I targeted LP scheme does serve to increase the capture of economic value from university research, above and beyond that of the non-targeted DP scheme. Regardless of whether or not U-I targeted grants are seeding collaboration, from a policy perspective the desired objective is still being achieved, of capturing economic benefit from research output. 


\section{Reference}

Adams, J., Griliches, Z. (1998). Research productivity in a system of universities. Annals of economics and statistics, 49-50, 127-162.

Altuzarra, A. (2019). R\&D and patents: is it a two way street? Economics of Innovation and New Technology, 28(2), 180-196.

Arellano, M., Bond, S. (1991). Some tests of specification for panel data: Monte Carlo evidence and an application to employment equations. Review of Economic Studies, 58, $277-297$.

Arellano, M., Bover, O. (1995). Another look at the instrumental variables estimation of error component models. Journal of Econometrics, 68, 29-51.

Arora, A., Ceccagnoli, M., Cohen, W. (2008). R\&D and the patent premium. International Journal of Industrial Organization, 26, 1153-1179.

Arora, A., Gambardella, A. (2005). The Impact of NSF Support for Basic Research In Economics. Annales d'Économie et de Statistique(79/80), 91-117.

Australian Research Council. (1999). Annual Report 1998-1999. Retrieved from http://hdl.voced.edu.au/10707/445273.

Australian Research Council. (2001). Annual Report 2000-2001. Retrieved from http://www.arc.gov.au/publications/default.htm

Australian Research Council. (2011). Discovery Projects Funding Rules for funding commencing in 2013. Canberra.

Australian Research Council. (2012). Linkage Projects Funding Rules for funding commencing in 2013. Canberra.

Australian Research Council. (2015). National Competitive Grants Program Dataset. Retrieved from http://www.arc.gov.au/grants-dataset

Australian Research Council. (2016). Funding Rules for schemes under the Linkage Programme (2016 edition). Retrieved from http://www.arc.gov.au/sites/default/files/filedepot/Public/NCGP/Funding\%20Rules/Li nkage_Program_Funding_Rules_2016.pdf.

Australian Research Council. (2017). National Competitive Grants Program Dataset NCGP Project and Fellowship Collection (Completed). Retrieved from http://www.arc.gov.au/grants-dataset

Australian Research Council Act (Cth), (2001).

Averch, H. (1987). Measuring the cost-efficiency of basic research investment: Input-output approaches. Journal of Policy Analysis and Management, 6(3), 342-361.

Azoulay, P., Graff Zivin, J., Li, D. \& Sampat, B. (2019). Public R\&D Investments and Private-sector Patenting: Evidence from NIH Funding Rules. The Review of Economic Studies, 86(1), 117-152.

Baraldi, A. L., Cantabene, C. \& Perani, G. (2014). Reverse causality in the R\&D-patents relationship: an interpretation of the innovation persistence. Economics of Innovation and New Technology, 23(3), 304-326.

Bartz-Zuccala, W., Mohnen, P. \& Schweiger, H. (2018). The Role of Innovation and Management Practices in Determining Firm Productivity. Comparative Economic Studies, 60(4), 502-530.

Beaudry, C. \& Allaoui, S. (2012). Impact of public and private research funding on scientific production: The case of nanotechnology. Research Policy, 41(9), 1589-1606.

Bercovitz, J. F. (2011). The mechanisms of collaboration in inventive teams: composition, social networks, and geography. Research Policy, 40, 81-93.

Bikard, M., Vakili, K. \& Teodoridis, F. (2018). When Collaboration Bridges Institutions: The Impact of University-Industry Collaboration on Academic Productivity. Organization Science. 30(2), 426-445. 
Blume-Kohout, M. E., Kumar, K. B. \& Sood, N. (2015). University R\&D Funding Strategies in a Changing Federal Funding Environment. Science and Public Policy, 42(3), 355368.

Blundell, R., Bond, S. (1998). Initial conditions and moment restrictions in dynamic panel data models. Journal of Econometrics, 87, 115-143.

Bond, S., Hoeffler, A., Temple, J. (2001). GMM estimation of empirical growth models, . Discussion Paper no. 2048.

Bornmann, L., Wallon, G. \& Ledin, A. (2008). Does the committee peer review select the best applicants for funding? An investigation of the selection process for two European molecular biology organization programmes. PLoS One, 3(10), e3480.

Bozeman, B. (2000). Technology transfer and public policy: a review of research and theory. Research Policy, 29(4), 627-655.

Bozeman, B., Gaughan, M. (2007). Impacts of grants and contracts on academic researchers' interactions with industry. Research Policy, 36, 694-707.

Brouwer, E., Kleinknecht, A. \& Mohnen, P. (2001). R\&D and Patents: Which way does the causality run? IDEAS Working Paper Series from RePEc, IDEAS Working Paper Series from RePEc, 2001.

Burt, R. (2005). Brokerage and Closure: An introduction to social capital (Clarneon lectures in management studies). Oxford; New York: Oxford University Press.

Carayol, N. \& Lanoë, M. (2017). The Impact of Project-Based Funding in Science: rnLessons from the ANR Experience. IDEAS Working Paper Series from RePEc, IDEAS Working

Paper Series from RePEc, 2017.

Cheah, S. (2016). Framework for measuring research and innovation impact. Innovation: Management, Policy \& Practice, 18(2), 212-232.

Chen, H., Roco, M. C., Son, J., Jiang, S., Larson, C. A. \& Gao, Q. (2013). Global nanotechnology development from 1991 to 2012: patents, scientific publications, and effect of NSF funding. Journal of Nanoparticle Research, 15(9).

Colatat, P. (2015). An organizational perspective to funding science: Collaborative novelty at DARPA. Research Policy, 44, 874-887.

Crepon, B., Duguet, E. \& Mairessec, J. (1998). Research, Innovation And Productivi[Ty: An Econometric Analysis At The Firm Level. Economics of Innovation and New Technology, 7(2), 115-158.

Crepon, B., Duguet, E. (1997). Estimating the innovation function from patent numbers: GMM on count panel data. Journal of Applied Economics, 12, 243-263.

D’Este, P. \& Perkmann, M. (2010). Why do academics engage with industry? The entrepreneurial university and individual motivations. The Journal of Technology Transfer, 36(3), 316-339.

Defazio, D. L., Andy; Wright, Mike. (2009). Funding incentives, collaborative dynamics and scientific productivity: Evidence from the EU framework program. Research Policy, 38, 293-305.

Etzkowitz, H. \& Leydesdorff, L. (2000). The dynamics of innovation: from National Systems and "Mode 2" to a Triple Helix of university-industry-government relations. Research Policy, 29(2), 109-123.

Fleming, L. M., S., Chen, D. (2007). Collaborative brokerage, generative creativity, and creative success. Administrative Science Quarterly, 52, 443-475.

Frietsch, R., Neuhäusler, P., Jung, T. \& Van Looy, B. (2014). Patent indicators for macroeconomic growth-the value of patents estimated by export volume. Technovation, 34(9), 546-558. 
Furman, J. L., Murray, F. \& Stern, S. (2012). Growing Stem Cells: The Impact of Federal Funding Policy on the U.S. Scientific Frontier. Journal of Policy Analysis \& Management, 31(3), 661-705.

Gieryn, T. F. (1981). The ageing of a science and its expoitation of innovation: lessons from $\mathrm{X}$-ray and radio astronomy. Scientometrics, 3, 325-334.

Griliches, Z. (1979). Issues in assessing the contribution of research and development to productivity growth. The Bell Journal of Economics, 10(1), 92-116.

Griliches, Z. (1990). Patent Statistics as Economic Indicators: A Survey. Journal of Economic Literature, 28(4), 1661-1707.

Grupp, H. (1998). Foundations of the Economics of Innovation - Theory, Measurement and Practice. Cheltenham: Edward Elgar.

Gush, J., Jaffe, A., Larsen, V. \& Laws, A. (2017). The effect of public funding on research output: the New Zealand Marsden Fund. New Zealand Economic Papers, 1-22.

Hall, B. (2011) Innovation and productivity, MERIT Working Paper Series 028. The Netherlands: United Nations University - Maastricht Economic and Social Reserach Institute on Innovation and Technology (MERIT).

Hall, B. \& Ziednonis, R. (2001). The patent paradox revisited: An empirical study of patenting in the U.S. semiconductor industry. RAND Journal of Economics, 32, 101128.

Hohberger, J., Almeida, P. \& Parada, P. (2015). The direction of firm innovation: The contrasting roles of strategic alliances and individual scientific collaborations. Research Policy, 44(8), 1473-1487.

Hunter, E., Perry, S., Currall, S. (2011). Inside multi-disciplinary science and engineering research centers: The impact of organizational clinate on invention disclosures and patents. Research Policy, 40, 1226-1239.

IP Australia. (2018). AusPat. http://pericles.ipaustralia.gov.au/ols/auspat/quickSearch.do

Jacob, B. A. \& Lefgren, L. (2011). The impact of research grant funding on scientific productivity. Journal of Public Economics, 95(9), 1168-1177.

Jaffe, A. (2008). The "Science of Science Policy": reflections on the important questions and the challenges they present. The Journal of Technology Transfer, 33(2), 131-139.

Jaffe, A. (2015). A framework for evaluating the beneficial impacts of publicly funded research. Retrieved from Motu: www.motu.org.nz/publications/motu-notes

James, S. D., Leiblein, M. J. \& Lu, S. (2013). How Firms Capture Value From Their Innovations. Journal of Management, 39(5), 1123-1155.

Kyvik, J., Hicks, D. . (2008). Does the aging of tenured academic staff affect the reserach performance of universities? Scientometrics, 76, 439-455.

Lanjouw, J. O., Pakes, A. \& Putnam, J. (1998). How to count patents and value intellectual property: The uses of patent renewal and application data. The Journal of Industrial Economics, 46(4), 405-432.

Lee, S., Bozeman, B. (2005). The impact of research collaboration on scientific productivity. Social Studies of Science, 35(5), 673-702.

Maietta, O. (2015). Determinants of university-firm R\&D collaboration and its impact on innovation: A perspective from a low-tech industry. Research Policy, 44, 1341-1359.

Martin-Vega, L. A., Seiford, L. M. \& Senich, D. (2002). GOALI: A National Science Foundation University-Industry Liaison Program. Interfaces, 32(2), 56-62.

Meyer, M. S. \& Tang, P. (2007). Exploring the "value” of academic patents: IP management practices in UK universities and their implications for Third-Stream indicators. Scientometrics, 70(2), 415-440.

Michael Carley, D. H. \& Alan, M. (2015). WHAT IS THE PROBABILITY OF RECEIVING A U.S. PATENT? Yale Journal of Law \& Technology, 17, 203-368. 
Mingji, J. \& Ping, Z. (2014). Research on the Patent Innovation Performance of UniversityIndustry Collaboration Based on Complex Network Analysis. Journal of Business-toBusiness Marketing, 21(2), 65-83.

National Board of Employment, E. a. T. (1990). Annual Report 1989-1990. Canberra. Retrieved from http://hdl.voced.edu.au/10707/8031.

OECD. (2017). OECD Science, Technology and Industry Scoreboard 2017: The digital transformation. Retrieved from Paris: http://dx.doi.org/10.1787/9789264268821-en

Payne, A., Siow, A. (2003). Does federal research funding increase university research output? Advances in Economic Analysis \& Policy, 3, 1018.

Ponomariov, B. (2013). Government-sponsored university-industry collaboration and the production of nanotechnology patents in US universities. The Journal of Technology Transfer, 38(6), 749-767.

Roodman, D. (2009). A note on the theme of too many instruments. Oxford Bulletin of Economics and Statistics, 71(1), 135-158.

Stoneman, P. (1983). Patents and R and D: Searching for a Lag Structure - Comment. Paper presented at the Conference on Quantitative Studies of Research and Development in Industry, Paris.

Sugimoto, C. R., Ni, C., West, J. D. \& Lariviere, V. (2015). The academic advantage: gender disparities in patenting. PLoS One, 10(5), e0128000.

Szücs, F. (2018). Research subsidies, industry-university cooperation and innovation. Research Policy, 47(7), 1256-1266.

Universities Australia. (2016). Higher Education Research Data Collection (HERDC) Time Series 1992 to 2015.

Van Looy, B., Landoni, P., Callaert, J., van Pottelsberghe, B., Sapsalis, E. \& Debackere, K. (2011). Entrepreneurial effectiveness of European universities: An empirical assessment of antecedents and trade-offs. Research Policy, 40(4), 553-564.

Zhou, W., Li, Y., Hsieh, C.-J., Chang, K.-C., Kiang, Y.-J. \& Ken, Y. (2016). Research Performance and University-Industry-Government Funding Sources in Taiwan's Technological and Vocational Universities. Innovation, 18(3), 340-351. 


\section{Appendix}

\section{Table A1}

University affiliation between 2001 and 2012.

\begin{tabular}{|c|c|}
\hline University & Affiliation \\
\hline $\begin{array}{l}\text { Australian National University } \\
\text { Monash University } \\
\text { The University of Adelaide } \\
\text { The University of Melbourne } \\
\text { The University of Queensland } \\
\text { The University of Sydney } \\
\text { The University of Western Australia } \\
\text { University of New South Wales }\end{array}$ & $\begin{array}{l}\text { Group of Eight Australia (Go8) } \\
\text { The Go8 was incorporated in } 1999 \text { and comprises } \\
\text { Australia's eight leading universities. Between them this } \\
\text { group accounts for two thirds of all research funding to } \\
\text { Australian Universities. } \\
\text { See https://go8.edu.au. }\end{array}$ \\
\hline $\begin{array}{l}\text { Curtin University } \\
\text { Queensland University of } \\
\text { Technology } \\
\text { RMIT University } \\
\text { University of South Australia } \\
\text { University of Technology Sydney }\end{array}$ & $\begin{array}{l}\text { Australian Technology Network of Universities (ATN) } \\
\text { The ATN brings together five of the 'most innovative and } \\
\text { enterprising universities in the nation'. ATN universities } \\
\text { describe themselves as modern, innovative, dynamic and } \\
\text { globally focused institutions with a focus on real-world } \\
\text { research. } \\
\text { See https://www.atn.edu.au. }\end{array}$ \\
\hline $\begin{array}{l}\text { Charles Darwin University }^{1} \\
\text { Flinders University } \\
\text { Griffith University } \\
\text { James Cook University }^{*^{2}} \\
\text { La Trobe University } \\
\text { Macquarie University } \\
\text { Murdoch University } \\
\text { The University of Newcastle }{ }^{* 4}\end{array}$ & $\begin{array}{l}\text { Innovative Research Universities (IRU) } \\
\text { The IRU is a policy group comprising Australian } \\
\text { universities, all of which were established as research- } \\
\text { intensive universities during the 1960s and 1970s. "The } \\
\text { IRU members' research is focussed at the translation of } \\
\text { research on issues of critical importance to the } \\
\text { communities in which they are based which address } \\
\text { problems of national and global scale." } \\
\text { See https://www.iru.edu.au. }\end{array}$ \\
\hline $\begin{array}{l}\text { Australian Catholic University } \\
\text { Bond University* } \\
\text { Central Queensland University* } \\
\text { Charles Sturt University* } \\
\text { Deakin University } \\
\text { Edith Cowan University } \\
\text { Swinburne University of Technology } \\
\text { University of Canberra } \\
\text { University of New England* } \\
\text { University of Southern Queensland* } \\
\text { University of Tasmania } \\
\text { University of the Sunshine Coast* } \\
\text { University of Western Sydney } \\
\text { University of Wollongong* } \\
\text { Victoria University }\end{array}$ & $\begin{array}{l}\text { Non-aligned universities } \\
\text { Universities not affiliated with the university networks } \\
\text { above. }\end{array}$ \\
\hline $\begin{array}{l}\text { * } \text { Regional universities. } \\
1 \text { joined the IRU in } 2009 . \\
2 \text { joined the IRU in } 2007 . \\
3 \text { withdrew from the IRU in } 2008 . \\
{ }^{4} \text { withdrew from the IRU in } 2014 .\end{array}$ & \\
\hline
\end{tabular}


Table A2

Fields of Research.

\begin{tabular}{|c|c|}
\hline FoR codes & ASRC divisions \\
\hline 01 Mathematical Sciences & 21 Science -General \\
\hline 02 Physical Sciences & 22 Social Sciences, Humanities and Arts - \\
\hline 03 Chemical Sciences & General \\
\hline 04 Earth Sciences & 23 Mathematical Sciences \\
\hline 05 Environmental Sciences & 24 Physical Sciences \\
\hline 06 Biological Sciences & 25 Chemical Sciences \\
\hline 07 Agriculture and Veterinary Sciences & 26 Earth Sciences \\
\hline 08 Information and Computing Sciences & 27 Biological Sciences \\
\hline 09 Engineering & 28 Information, Computing and \\
\hline 10 Technology & Communication Sciences \\
\hline 11 Medical and Health Sciences & 29 Engineering and Technology \\
\hline 12 Built Environment and Design & 30 Agricultural, Veterinary and \\
\hline 13 Education & Environmental Sciences \\
\hline 14 Economics & 31 Architecture, Urban Environment and \\
\hline 15 Commerce, Management, Tourism and & Building \\
\hline Services & 32 Medical and Health Sciences \\
\hline 16 Studies in Human Society & 33 Education \\
\hline 17 Psychology and Cognitive Sciences & 34 Economics \\
\hline 18 Law and Legal Studies & 35 Commerce, Management, Tourism and \\
\hline 19 Studies in Creative Arts and Writing & Services \\
\hline 20 Language, Communication and Culture & 36 Policy and Political Science \\
\hline 21 History and Archaeology & 37 Studies in Human Society \\
\hline \multirow[t]{8}{*}{22 Philosophy and Religious Studies } & 38 Behavioural and Cognitive Sciences \\
\hline & 39 Law, Justice and Law Enforcement \\
\hline & 40 Journalism, Librarianhip and Curatorial \\
\hline & Studies \\
\hline & 41 The Arts \\
\hline & 42 Language and Culture \\
\hline & 43 History and Archaeology \\
\hline & 44 Philosophy and Religion \\
\hline
\end{tabular}

ARC grants with a Field of Research (FoR) code of 01 to 12 or Australian Standard Research Classification (ASRC) of 23 to 32 were included in the study. The FoR codes were introduced in 2008 replacing the ASRC.

Across the 36 universities in the sample, $71.8 \%$ of U-I targeted grants and $72.1 \%$ of non-targeted grants had an FoR code of 01 to 12, or the equivalent ASRC code, between 2001 and 2012. 


\section{Table A3}

Data source of variables contributing to university research environment.

\begin{tabular}{ll}
\hline University variable & Source \\
\hline Number of researchers & Selected Higher Education Statistics, Department of \\
& Education and Training Higher Education \\
Number of articles published in & Higher Education Research Data Collection, \\
scholarly refereed journals & Department of Education and Training \\
Number of total commercialization & National Survey of Research Commercialization, \\
staff & Department of Industry, Innovation and Science \\
\hline
\end{tabular}




\section{Table A4}

Variance Inflation Factors for university variables.

\begin{tabular}{|c|c|c|c|c|c|c|c|c|c|c|}
\hline & $\begin{array}{l}(1) \\
\text { Patent } \\
\text { applications }\end{array}$ & & $\begin{array}{l}(2) \\
\text { Patent } \\
\text { applications }\end{array}$ & & $\begin{array}{l}\text { (3) } \\
\text { Patent } \\
\text { applications }\end{array}$ & & $\begin{array}{l}\text { (4) } \\
\text { Patent } \\
\text { applications }\end{array}$ & & $\begin{array}{l}\text { (5) } \\
\text { Granted } \\
\text { patents }\end{array}$ & \\
\hline Linkage grants & $0.203^{* *}$ & 13.01 & $0.160^{* * *}$ & 4.42 & $0.136^{* * *}$ & 4.33 & $0.190^{* * *}$ & 3.80 & $0.131^{* * *}$ & 3.80 \\
\hline Discovery grants & 0.0845 & 70.08 & 0.0368 & 8.55 & $0.0594^{* *}$ & 8.13 & $0.0944^{* * *}$ & 5.64 & $0.0349^{* *}$ & 5.64 \\
\hline Linkage Funding (\$) & -0.000000183 & 11.41 & & & & & & & & \\
\hline Discovery Funding (\$) & -0.000000143 & 64.69 & & & & & & & & \\
\hline Non-affiliated & 0 & & 0 & & 0 & & 0 & & 0 & \\
\hline Go8 & 0.471 & 8.48 & 0.767 & 8.23 & 0.541 & 8.21 & 1.755 & 6.02 & 1.104 & 6.02 \\
\hline ATN & -0.326 & 1.47 & -0.227 & 1.45 & 0.0986 & 1.42 & 0.174 & 1.45 & 0.0287 & 1.45 \\
\hline IRU & -0.786 & 1.37 & -0.712 & 1.35 & -0.601 & 1.34 & -0.443 & 1.41 & -0.101 & 1.41 \\
\hline Research funding & $-3.24 \mathrm{e}-08^{* * *}$ & 20.00 & $-3.69 \mathrm{e}-08^{* * *}$ & 17.69 & & & & & & \\
\hline University publications & $0.00477^{* * *}$ & 25.28 & $0.00512^{* * *}$ & 24.20 & $0.00176^{*}$ & 12.03 & & & & \\
\hline Research staff & 0.00234 & 16.60 & 0.00180 & 15.66 & 0.000550 & 15.05 & & & & \\
\hline Commercialization staff & $0.0292^{*}$ & 1.33 & $0.0290^{*}$ & 1.33 & $0.0272^{*}$ & 1.33 & & & & \\
\hline Time (year) & $-0.172^{* *}$ & 1.83 & $-0.193^{* *}$ & 1.74 & $-0.215^{* * *}$ & 1.73 & -0.0709 & 1.06 & 0.0287 & 1.06 \\
\hline Publications per researcher & & & & & & & 0.00274 & 1.20 & 0.00325 & 1.20 \\
\hline $\begin{array}{l}\text { Commercialisation staff per } \\
\text { researcher }\end{array}$ & & & & & & & 0.478 & 1.10 & 0.263 & 1.10 \\
\hline Constant & $343.4^{* *}$ & & $385.7^{* *}$ & & $430.2^{* * *}$ & & 142.4 & & -57.73 & \\
\hline Observations & 420 & & 420 & & 420 & & 407 & & 407 & \\
\hline
\end{tabular}

Notes: VIF in second column. ${ }^{*} p<0.05,{ }^{* *} p<0.01,{ }^{* * *} p<0.001$ 
Table A5

Models for the effect of ARC project grants on inventor patent applications - controls.

\begin{tabular}{|c|c|c|c|}
\hline Dep. Var. & $\begin{array}{c}\text { (4) } \\
\text { Patent apps }\end{array}$ & $\begin{array}{c}\text { (5) } \\
\text { Patent appls }\end{array}$ & $\begin{array}{c}\text { (6) } \\
\text { U-I targ }\end{array}$ \\
\hline Academic age (as of 2012) & $\begin{array}{c}0.012 * * * \\
(0.002) \\
0.002\end{array}$ & $\begin{array}{c}0.000 \\
(.)\end{array}$ & $\begin{array}{c}0.000 \\
(.)\end{array}$ \\
\hline Female & $\begin{array}{l}-0.052 \\
(0.037) \\
-0.007\end{array}$ & $\begin{array}{c}0.000 \\
(.)\end{array}$ & $\begin{array}{c}0.000 \\
(.)\end{array}$ \\
\hline ARC Fellowships & $\begin{array}{c}0.372^{*} \\
(0.155) \\
0.050\end{array}$ & $\begin{array}{c}0.051 \\
(0.052)\end{array}$ & $\begin{array}{l}-0.042 \\
(0.036)\end{array}$ \\
\hline Go8 & $\begin{array}{c}0.027 \\
(0.085) \\
0.004\end{array}$ & & $\begin{array}{c}0.000 \\
(.)\end{array}$ \\
\hline ATN & $\begin{array}{l}-0.075 \\
(0.087) \\
-0.010\end{array}$ & & $\begin{array}{c}0.000 \\
(.)\end{array}$ \\
\hline IRU & $\begin{array}{l}-0.102 \\
(0.091) \\
-0.013\end{array}$ & & $\begin{array}{c}0.000 \\
(.)\end{array}$ \\
\hline Pubs/researcher (uni avg) & $\begin{array}{c}0.005 \\
(0.008) \\
0.001\end{array}$ & $\begin{array}{l}-0.001 \\
(0.003)\end{array}$ & $\begin{array}{c}0.000 \\
(0.001)\end{array}$ \\
\hline Comm staff/researcher (uni avg) & $\begin{array}{c}-0.566^{* * *} \\
(0.147) \\
-0.076\end{array}$ & $\begin{array}{c}0.169 \\
(0.260)\end{array}$ & $\begin{array}{l}-0.029 \\
(0.097)\end{array}$ \\
\hline Scopus field of research & Incl. & Incl. & Incl. \\
\hline $\begin{array}{l}\text { Obs. } \\
\text { N Inventor } \\
\text { Log likelihood } \\
\text { Wald } \chi^{2}\end{array}$ & $\begin{array}{c}22788 \\
1899 \\
-9205.2\end{array}$ & 17091 & 17091 \\
\hline Prob. $>\chi 2$ & . & 0.000 & 0.590 \\
\hline
\end{tabular}


Table A6

Models for the effect of ARC project grants on inventor patent grants - controls.

\begin{tabular}{|c|c|c|c|}
\hline Dep. Var. & $\begin{array}{c}(4) \\
\text { Patent grants } \\
\end{array}$ & $\begin{array}{c}\text { (5) } \\
\text { Patent grants } \\
\end{array}$ & $\begin{array}{c}6) \\
\text { U-I targ }\end{array}$ \\
\hline \multirow[t]{2}{*}{ Academic age (as of 2012) } & $\begin{array}{c}0.010^{* * *} \\
(0.003)\end{array}$ & $\begin{array}{c}0.000 \\
(.)\end{array}$ & $\begin{array}{c}0.000 \\
(.)\end{array}$ \\
\hline & 0.001 & & \\
\hline \multirow[t]{3}{*}{ Female } & -0.050 & & \\
\hline & $(0.066)$ & & \\
\hline & -0.003 & & \\
\hline \multirow[t]{3}{*}{ ARC Fellowships } & 0.287 & 0.035 & -0.031 \\
\hline & $(0.220)$ & $(0.031)$ & $(0.036)$ \\
\hline & 0.020 & & \\
\hline \multirow[t]{3}{*}{ Go8 } & 0.040 & & \\
\hline & $(0.109)$ & & \\
\hline & 0.003 & & \\
\hline \multirow[t]{3}{*}{ ATN } & -0.084 & & \\
\hline & $(0.125)$ & & \\
\hline & -0.006 & & \\
\hline \multirow[t]{3}{*}{ IRU } & -0.142 & & \\
\hline & $(0.132)$ & & \\
\hline & -0.009 & & \\
\hline \multirow[t]{3}{*}{ Pubs/researcher (uni avg) } & 0.014 & 0.003 & 0.000 \\
\hline & $(0.011)$ & $(0.003)$ & $(0.002)$ \\
\hline & 0.001 & & \\
\hline \multirow[t]{3}{*}{ Comm staff/researcher (uni avg) } & $-0.426 *$ & -0.285 & -0.001 \\
\hline & $(0.178)$ & $(0.196)$ & $(0.138)$ \\
\hline & -0.030 & & \\
\hline Scopus field of research & Incl. & Incl. & Incl. \\
\hline
\end{tabular}




\section{Table A7}

Appropriateness of GMM estimator.

\begin{tabular}{|c|c|c|c|c|c|c|c|c|c|c|c|c|c|}
\hline \multirow[t]{2}{*}{ Estimator } & \multicolumn{3}{|c|}{$\begin{array}{c}\text { Co-efficient of 1-year lag } \\
\text { patent applications }\end{array}$} & \multicolumn{3}{|c|}{$\begin{array}{c}\text { Co-efficient of 1-year lag U-I targ } \\
\text { (patent applications) }\end{array}$} & \multicolumn{3}{|c|}{$\begin{array}{c}\text { Co-efficient of 1-year lag } \\
\text { granted patents }\end{array}$} & \multicolumn{3}{|c|}{$\begin{array}{c}\text { Co-efficient of 1-year lag U-I targ } \\
\text { (granted patents) }\end{array}$} & \multirow[b]{2}{*}{$\begin{array}{c}\text { Num. } \\
\text { instruments }\end{array}$} \\
\hline & Co-eff & $\begin{array}{l}\text { AR } \\
(2)\end{array}$ & $\begin{array}{c}\text { Hansen test } \\
\text { p-val }\end{array}$ & Co-eff & $\begin{array}{l}\text { AR } \\
(2)\end{array}$ & $\begin{array}{c}\text { Hansen test } \\
\text { p-val }\end{array}$ & Co-eff & $\begin{array}{l}\text { AR } \\
(2)\end{array}$ & $\begin{array}{c}\text { Hansen test } \\
\text { p-val }\end{array}$ & Co-eff & $\begin{array}{c}\text { AR } \\
(2)\end{array}$ & $\begin{array}{c}\text { Hansen test } \\
\text { p-val }\end{array}$ & \\
\hline Pooled OLS & .0389 & & & .0944 & & & .0515 & & & .0946 & & & \\
\hline Fixed effect & -.0343 & & & -.1414 & & & -.0502 & & & -.1410 & & & \\
\hline \multicolumn{14}{|c|}{ Collapsed } \\
\hline $\begin{array}{l}\text { One-step Diff. } \\
\text { GMM }\end{array}$ & .0548 & .151 & .186 & -.0696 & .232 & .017 & .0614 & .619 & .501 & -.0646 & .258 & .069 & 42 \\
\hline $\begin{array}{l}\text { Two-step Diff. } \\
\text { GMM }\end{array}$ & .0437 & .163 & .186 & -.0654 & .485 & .017 & .0561 & .890 & .501 & -.0595 & .506 & .069 & 42 \\
\hline $\begin{array}{l}\text { One-step Sys. } \\
\text { GMM }\end{array}$ & .0528 & .167 & .127 & -.0662 & .278 & .015 & .0592 & .875 & .363 & -.0636 & .198 & .044 & 49 \\
\hline $\begin{array}{l}\text { Two-step Sys. } \\
\text { GMM }\end{array}$ & .0403 & .157 & .127 & -.0687 & .575 & .052 & .0454 & .797 & .363 & -.0637 & .485 & .044 & 49 \\
\hline \multicolumn{14}{|c|}{ Not collapsed } \\
\hline $\begin{array}{l}\text { One-step Diff. } \\
\text { GMM }\end{array}$ & .0555 & .129 & .001 & -.0682 & .115 & .061 & .0515 & .181 & .000 & -.0627 & .084 & .019 & 174 \\
\hline $\begin{array}{l}\text { Two-step Diff. } \\
\text { GMM }\end{array}$ & .0295 & .151 & .001 & -.0488 & .389 & .061 & .0215 & .891 & .000 & -.0429 & .437 & .019 & 174 \\
\hline $\begin{array}{l}\text { One-step Sys. } \\
\text { GMM }\end{array}$ & .0647 & .042 & .000 & -.0057 & .004 & .068 & .0649 & .704 & .000 & -.0019 & .002 & .032 & 208 \\
\hline $\begin{array}{l}\text { Two-step Sys. } \\
\text { GMM }\end{array}$ & .0462 & .206 & .000 & .0016 & .045 & .068 & .0397 & .789 & .000 & .0065 & .026 & .032 & 208 \\
\hline
\end{tabular}




\section{Table A8}

Models for the effect of ratio ARC Project grants on university patent activity (12-year aggregate) - controls.

\begin{tabular}{|c|c|c|c|c|}
\hline Dep. Var. & $\begin{array}{c}\text { (1) } \\
\text { Patent apps }\end{array}$ & $\begin{array}{c}(2) \\
\text { Patent apps }\end{array}$ & $\begin{array}{c}\text { (3) } \\
\text { Patent grants }\end{array}$ & $\begin{array}{c}\text { (4) } \\
\text { Patent grants }\end{array}$ \\
\hline \multirow[t]{2}{*}{ Go8 } & -0.010 & 0.027 & 0.235 & 0.292 \\
\hline & (0.419) & $(0.423)$ & $(0.428)$ & $(0.421)$ \\
\hline \multirow[t]{2}{*}{ ATN } & $0.511 \dagger$ & 0.358 & $0.684 *$ & $0.552 *$ \\
\hline & $(0.265)$ & $(0.270)$ & $(0.271)$ & $(0.269)$ \\
\hline \multirow[t]{2}{*}{ IRU } & -0.227 & -0.134 & 0.029 & 0.165 \\
\hline & $(0.317)$ & $(0.321)$ & (0.307) & $(0.293)$ \\
\hline \multirow[t]{2}{*}{ Pubs/researcher } & -0.053 & -0.050 & -0.036 & -0.031 \\
\hline & $(0.036)$ & $(0.035)$ & $(0.036)$ & $(0.035)$ \\
\hline \multirow[t]{2}{*}{ Comm staff/rearcher } & 0.123 & 0.026 & 0.184 & 0.084 \\
\hline & $(0.238)$ & $(0.210)$ & $(0.273)$ & $(0.235)$ \\
\hline
\end{tabular}

Notes: $\dagger p<0.1, * p<0.05, * * p<0.01, * * * p<0.001$. NBREG regression. Standard errors are shown in in parentheses. 


\section{Table A9}

Models for the effect of ratio ARC Project grants on inventor patent activity (12-year aggregate) - controls.

\begin{tabular}{lcccc}
\hline Dep. Var. & $\begin{array}{c}(1) \\
\text { Patent apps }\end{array}$ & $\begin{array}{c}(2) \\
\text { Patent apps }\end{array}$ & $\begin{array}{c}(3) \\
\text { Patent grants }\end{array}$ & $\begin{array}{c}(4) \\
\text { Patent grants }\end{array}$ \\
\hline Academic age (as of & $0.011^{* * *}$ & $0.011^{* * *}$ & $0.008^{*}$ & $0.008^{*}$ \\
2012) & $(0.003)$ & $(0.003)$ & $(0.004)$ & $(0.004)$ \\
Female & -0.106 & -0.106 & -0.117 & -0.117 \\
& $(0.070)$ & $(0.070)$ & $(0.117)$ & $(0.117)$ \\
ARC Fellowship & $0.184^{* *}$ & $0.183^{* *}$ & 0.122 & 0.121 \\
& $(0.070)$ & $(0.071)$ & $(0.104)$ & $(0.105)$ \\
Go8 & 0.155 & 0.158 & 0.222 & 0.225 \\
& $(0.152)$ & $(0.152)$ & $(0.190)$ & $(0.191)$ \\
ATN & & & & -0.005 \\
& 0.020 & 0.012 & 0.001 & $(0.216)$ \\
IRU & $(0.150)$ & $(0.151)$ & $(0.214)$ & -0.041 \\
& -0.071 & -0.070 & -0.040 & $(0.209)$ \\
Pubs/researcher (uni & $(0.157)$ & $(0.157)$ & $(0.210)$ & 0.013 \\
avg) & 0.019 & 0.020 & 0.013 & $(0.032)$ \\
Comm staff/researcher & $(0.014)$ & $(0.014)$ & $(0.032)$ & 0.302 \\
(uni avg) & -0.107 & -0.081 & 0.277 & $(0.207)$ \\
& & & & Incl. \\
Scopus field of & $(0.204)$ & $(0.204)$ & $(0.204)$ & Incl. \\
research & Incl. & Incl. & & \\
\hline Notes: $\dagger p<0.1, * p<0.05, * * *$ \\
parentheses.
\end{tabular}

